\title{
The Role of Sustainable Technological Innovations in the Relationship between Freight Pricing and Environmental Degradation: Evidence from a Panel of 39 R\&D economies
}

\author{
Muhammad Khalid ANSER ${ }^{1}$, Sajid $\mathrm{ALI}^{2}$, Muhammad Azhar KHAN ${ }^{3}$, Abdelmohsen A. NASSANI ${ }^{4}$, \\ Sameh E. ASKAR ${ }^{5}$, Khalid ZAMAN ${ }^{3 *}$, Muhammad Moinuddin QAZI ABRO ${ }^{4}$ and Ahmad KABBANI ${ }^{6}$ \\ ${ }^{1}$ School of Public Administration, Xi'an University of Architecture and Technology, Xi'an 710000, China. \\ ${ }^{2}$ School of Economics, Bahauddin Zakariya University, Multan, Pakistan. \\ ${ }^{3}$ Department of Economics, University of Haripur, Khyber Pakhtunkhwa, Haripur, Pakistan \\ ${ }^{4}$ Department of Management, College of Business Administration, King Saud University, PO Box 71115, Riyadh, \\ 11587, Saudi Arabia. \\ ${ }^{5}$ Department of Statistics and Operations Research, College of Science, King Saud University, PO Box 11451, Riyadh \\ 11587 Saudi Arabia. \\ ${ }^{6}$ Department of Management, Aleppo University, Aleppo, Syria. \\ *Corresponding author: khalid_zaman786@yahoo.com
}

Received: June 07, 2020; Accepted: December 08, 2020

\begin{abstract}
RESUMEN
Este estudio está en línea con la Convención Marco de las Naciones Unidas sobre el Cambio Climático (CMNUCC) para evaluar el Acuerdo post-París (COP21) a través de innovaciones tecnológicas y fijación de precios del carbono en un panel de 39 economías de I + D desde 1995 hasta 2018. Los resultados muestran que las innovaciones tecnológicas y las aplicaciones inteligentes de los servicios financieros y de seguros ayudan a reducir las emisiones de GEI en la distribución de cuantiles desde más bajos a más altos. Por el contrario, el transporte aéreo de mercancías, los precios del transporte aéreo y el flujo de inversión extranjera directa (IED) aumentan las emisiones de gases de efecto invernadero debido a actividades logísticas no sostenibles, precios de transporte ineficientes y producción sucia, confirmando la hipótesis del 'paraíso de contaminación' en todos los países. Los ingresos por flete aéreo tienen un impacto diferencial en las emisiones de GEI en la distribución de cuantiles, ya que en los cuantiles más bajos $\left(\tau_{0.2}\right.$ a $\left.\tau_{0.4}\right)$ los ingresos por flete aéreo aumentan emisiones de GEI, mientras que en los cuantiles más altos $\left(\tau_{0.9}\right)$, las disminuyen. Por lo tanto, la viabilidad de los ingresos por transporte aéreo se evalúa a mayor profundidad utilizando la matriz de innovación de panel y causalidad de Panel Granger. Los resultados muestran causalidad bidireccional entre i) los precios del flete aéreo y las emisiones de gases de efecto invernadero, ii) el flete del transporte aéreo (y el precio del flete, los ingresos por flete, la IED) y las innovaciones tecnológicas, iii) la IED y los ingresos del flete aéreo, mientras que existe una causalidad unidireccional desde i) seguros y servicios financieros a emisiones de GEI, ii) emisiones de GEI a innovaciones tecnológicas y flujos de IED, y iii) fletes de transporte aéreo a flujos de IED.
\end{abstract}

\section{ABSTRACT}

This study is in line with the United Nations Framework Convention on Climate Change (UNFCCC) to evaluate the post-Paris Agreement (COP21) through technological innovations and carbon pricing in a panel of 39 R\&D economies from 1995 to 2018. The results show that sustainable technological innovations and smart applications of insurance and financial services help decrease GHG emissions in the lowest to highest quantile distribution. In contrast, air transportation freight, air freight pricing, and foreign direct investment (FDI) inflows escalate GHG emissions due to unsustainable logistics activities, inefficient freight pricing, 
and dirty production, which confirmed the 'pollution haven' hypothesis across countries. The impact of air freight revenues has a differential impact on GHG emissions in the different quantiles' distribution, as in the lowest quantiles (i.e., $\tau_{0.2}$ to $\tau_{0.4}$ ), air freight revenues increase GHG, whereas, at the highest quantiles' distribution (i.e., $\tau_{0.9}$ ) emissions decrease. Thus, the viability of air freight revenues is further assessed using Panel Granger causality and panel innovation matrix. The results show the bidirectional causality between i) air freight pricing and GHG emissions, ii) air transportation freight (and freight pricing, freight revenues, FDI) and technology innovations, iii) FDI and air freight revenues, while there is a unidirectional causality running from i) insurance and financial services to GHG emissions, ii) GHG emissions to technological innovations and FDI inflows, and iii) air transportation freight to FDI inflows.

Keywords: Technological innovation, Air freight; Freight revenue, GHG emissions, Inbound FDI, Panel regression.

\section{Introduction}

The UNFCCC (2017) report on technological innovation and climate-resilient action plan is highly embarked on the post-Paris agreement, previously agreed among the United Nation (UN) member countries to combat climate change and mitigate GHG emissions within a global partnership and cooperation in the Paris Conference of the Parties (COP21) in 2015. The COP21 agenda set out a vision of low carbon and climate-resilient technologies to maintain the global temperature of less than $1.5^{\circ} \mathrm{C}$. Climate change effects threaten the 2030 agenda of international sustainable development, which would be handled by national adaptation plans and mutual coordinated action plans. Given this scenario, the role of technological innovation is to enhance efforts to implement global climate actions with integrated economic and environmental national policies towards green development. The latest IPCC (2018) report informed that global warming continues to increase, negatively impacting goal to keep global average temperature below $1.5^{\circ} \mathrm{C}$. The need for a reduction in carbon emissions by almost half by 2030 and reaching net-zero carbon emission by 2050 is required to achieve the COP21climate goals. Countries require an integrated set of national and mutually coordinated action policies, including science, technology and innovation policies, that would help cut GHG emissions globally. The CIGI (2017) report presented four alternative ways to achieve the environmental sustainability agenda of low carbon emissions, i.e., the establishment of innovative carbon emissions' mitigation global fund, sustainable contract programs related to financial performance, international environmental regulatory programs, and the formation of a green infrastructure development program. These programs would be highly decarbonizing and advance climate mitigation action reforms. Table I shows current facts and figures about computer technology progression, freight pricing and GHG emissions in a panel of 39 R \& D economies used in this study for more robust policy inferences.

The study seeks answers to three research questions to devise sustainable environmental policies. The first question is: Does technology innovation help limit $G H G$ emissions to maintain global average temperature below $1.5^{\circ} \mathrm{C}$ ? This research question would be helpful to assess efficient green Information and Communication Technology (ICTs) policies in a panel of selected R\&D economies in line with the Kyoto Protocol and Paris Agreement (COP21) (Dogan \& Ozturk, 2017). The transportation sector is highly responsible for escalating GHG emissions due to its unsustainable logistics activities; thus, freight pricing would be an optimal solution to cut GHG emissions through a carbon tax and emissions -cap trading (Salahuddin et al. 2016).

The second research question is: To what extent air freight pricing could reduce GHG emissions through managing air freight revenue for reinvesting in cleaner sustainable options? This question supports innovative technology mechanisms and synergy with the sustainable policy agenda through a freight tax, which provides more investment opportunities in cleaner options to protect the natural environment and comply with the Kyoto protocol (Usman et al. 2020).

Finally, the 'pollution haven' hypothesis is evaluated across a panel of selected countries, which we assume to be true due to un-green financial policies; thus, the third question is: Does foreign direct investment (FDI) inflows increase GHG emissions due to lax environmental regulations and financial 
Table I. Current Facts for Information Technology, Freight Pricing, and GHG Emissions

\begin{tabular}{|c|c|c|c|c|c|c|c|}
\hline Countries & $\begin{array}{l}\text { Computer } \\
\text { communication } \\
(\% \text { of } \\
\text { commercial } \\
\text { service } \\
\text { exports })\end{array}$ & $\begin{array}{l}\text { Freight } \\
\text { Pricing } \\
(\%)\end{array}$ & $\begin{array}{l}\text { GHG emissions } \\
\text { (kt of } \mathrm{CO} 2 \\
\text { equivalent) }\end{array}$ & Countries & $\begin{array}{l}\text { Computer } \\
\text { communication } \\
(\% \text { of } \\
\text { commercial } \\
\text { service } \\
\text { exports })\end{array}$ & $\begin{array}{l}\text { Freight } \\
\text { Pricing } \\
\quad(\%)\end{array}$ & $\begin{array}{c}\text { GHG } \\
\text { emissions } \\
\text { (kt of } \mathrm{CO} 2 \\
\text { equivalent) }\end{array}$ \\
\hline United States & 45.685 & 2.442 & 6343841 & Finland & 72.538 & 1.083 & 69072.94 \\
\hline China & 60.764 & 2.074 & 12064260 & Czech Republic & 49.036 & 2.149 & 138957.4 \\
\hline Japan & 55.001 & 0.979 & 1478859 & Egypt & 9.971 & 29.501 & 295499.7 \\
\hline Germany & 55.219 & 1.732 & 951716.7 & South Africa & 20.576 & 4.504 & 502130.3 \\
\hline India & 72.227 & 4.860 & 3002895 & Portugal & 25.116 & 0.993 & 72524.22 \\
\hline France & 54.538 & 1.850 & 499146.6 & Thailand & 14.537 & 1.063 & 440411.7 \\
\hline UK & 46.525 & 2.292 & 585779.8 & Ukraine & 51.570 & 10.951 & 404900.3 \\
\hline Russian & & & & & & & \\
\hline Federation & 44.169 & 2.878 & 2803398 & Greece & 10.298 & 0.625 & 100571.2 \\
\hline Brazil & 60.546 & 3.664 & 2989418 & Pakistan & 65.177 & 5.078 & 369734.6 \\
\hline Italy & 39.980 & 1.137 & 482634 & Indonesia & 31.191 & 3.198 & 780550.8 \\
\hline Canada & 50.321 & 2.268 & 1027064 & New Zealand & 17.779 & 1.598 & 78130.98 \\
\hline Australia & 19.698 & 1.911 & 761686.3 & Saudi Arabia & 2.526 & 2.465 & 514967.3 \\
\hline Spain & 34.301 & 1.675 & 3482.57 .3 & Colombia & 18.940 & 3.240 & 173411.8 \\
\hline Turkey & 6.974 & 16.332 & 445640.1 & Chile & 31.976 & 2.434 & 120687.9 \\
\hline Switzerland & 51.566 & 0.936 & 54108.1 & Slovenia & 34.113 & 1.738 & 21074.75 \\
\hline Belgium & 58.787 & 2.053 & 133373.7 & Morocco & 35.848 & 1.912 & 80436.72 \\
\hline Austria & 40.645 & 1.998 & 90460.21 & Romania & 58.407 & 4.625 & 121762.2 \\
\hline Poland & 49.831 & 1.812 & 414606.9 & Belarus & 45.161 & 4.872 & 109647.2 \\
\hline Malaysia & 35.933 & 0.884 & 279098.4 & Singapore & 42.227 & 0.438 & 55901.28 \\
\hline Mexico & 0.507 & 4.899 & 663425 & & & & \\
\hline & & & & \multirow{3}{*}{\multicolumn{4}{|c|}{$\begin{array}{l}\text { Total Countries: } 39 \\
\text { Time Period: 1995-2018 } \\
\text { Data Reported Period: } 2018\end{array}$}} \\
\hline & & & & & & & \\
\hline & & & & & & & \\
\hline
\end{tabular}

Source: World Bank (2019).

liberalization policies? This question is important to analyze countries' sustainable development efforts that may be influenced by meager environmental policies and unconditional financial agreements, which does not generally favor the UN sustainable development goals (Khan \& Ozturk, 2020).

These research questions allow to set clear objectives for this study that would help to devise longterm and broad-based sustainable policies:

i) To investigate the role of technology innovation in mitigating GHG emissions across a panel of selected R\&D economies

ii) To analyze the role of air freight pricing and freight revenues on the growth of GHG emissions and iii) To assess to what extent financial liberalization policies influenced countries' efforts to mitigate GHG emissions to comply with the Kyoto protocol and COP21 Paris agreement.

\section{Literature Review}

Earlier literature findings largely work around the environmental sustainability agenda through multifaceted socio-economic and technological factors, providing a path to understanding sustainability issues in different economic settings. For instance, Zhang et al. (2013) discussed the importance of synthetic nitrogen fertilizer in food production to feed half of the world's population. However, the overuse of nitrogen fertilizer negatively influenced water quality, 
soil, and the atmosphere. The central question in the environmental agenda remains how to mitigate emissions through sustainable technologies, optimally decreasing excessive fertilizer use across countries. Lybbert and Sumner (2012) found a two-way channel as climate change negatively influenced agricultural production, while conventional agriculture produces GHG emissions through unsustainable practices. Thus, the development of new agricultural technologies and practices helps increase yield and reduce GHG emissions to achieve green agriculture development. Developing countries face severe challenges of low agricultural productivity, high poverty, greater inequality, and food insecurity.

Long et al. (2016) found many potential barriers that restrain the possible way of mitigating GHG emissions through climate-smart agriculture technologies, including the users' constraints from the demand side and technology providers' constraints on the supply side. The supply-side barriers include convincing customers to use new technologies for climate-smart agriculture, high capital requirement, regulatory issues, technology pricing, and end-user delivery. In contrast, the demand side issues include low technology awareness, high cost, uncertainty about technology and its positive impact, less training for technology use, and low consumer demand. These are the factors that diffuse technology innovation across Europe.

Williams et al. (2012) suggested the number of channels through which the global GHG emissions reduction target would be achieved by 2050 , including achieving energy efficiency through sustainable energy supply to help generate transportation demand technologies for green development. Nikzad and Sedigh (2017) discussed the viability of green technologies to mitigate GHG emissions in Canada. Advancement in alternative green energy sources, sustainable transportation systems, and energy conservation are a few sustainable options to achieve sustainable development by decreasing GHG emissions countrywide. Lukkarinen et al. (2018) considered Finland as case study and analyzed the role of clean technological policies in reducing emissions and found that the Cleantech Program is an effective tool to analyze innovation dynamics based upon market information and experimentation. Thus, the need for clean technologies is imperative for launching successful cleantech products that support renewable energy and material sources. Bel and Joseph (2018) suggested the need to critically evaluate carbon pricing policy instruments in the European Union emissions trading that has a crucial impact on technology adaptation in the energy sector. Fernández- Fernández et al. (2018) analyzed the dynamic interaction between technology innovation and carbon emissions in a panel of 15 European countries, the US, and China, for 1990-2013. Their results show that technology innovation positively impacts environmental quality and mitigates carbon emissions across countries. Energy demand is a significant predictor for negative environmental impacts and increased carbon emissions in China and the US but is relatively low in the European region. The results emphasized the need to increase R\&D spending in achieving the environmental sustainability agenda to mitigate GHG emissions from the production process. Nunes et al. (2019) analyzed the role of biomass energy in the Portuguese textile industry's sustainable growth that is less competitive due to high energy costs. After a thorough empirical survey, the results show that biomass energy can be used efficiently in the textile industry to become more competitive through up to $35 \%$ cost-saving energy compared to steam generation. Thus, R\&D spending in biomass energy production may become a viable, sustainable instrument to achieve green energy development. Yusuf et al. (2019) examined the role of technological innovation in reducing carbon emissions in the Indonesian economy over the period 1980-2017 and found the existence of a technology induced environmental Kuznets curve. The study concludes that high-technology exports are important to revitalize economic and environmental policies to lessen high carbon abatement costs across the globe. Liu et al. (2019) found the different drivers of GHG emissions across 40 heterogeneous countries analyzing the period 1995-2009 and show that continued global economic growth is one of the main factors of increased GHG emissions while achieving energy efficiency after surpassed the certain income threshold reduces global GHG emissions. Another important factor is technological innovation that has a certain positive impact on environmental quality. The investment effect shows some evidence of the 'pollution haven' hypothesis that exhibit polluting 
industries in different countries. The viability of sustainable environmental policies is imperative to mitigate GHG emissions across the globe. Miyamoto and Takeuchi (2019) argued that the Kyoto Protocol has a significant impact on international patenting applications that reduce energy associated emissions by increasing R\&D spending on renewable energy technologies. Thus, climate agreements largely concentrated on global patenting technologies. Table II shows the different technology innovation factors that are largely used in previous studies under the environmental sustainability agenda domain.

The study's research objectives have been empirically analyzed at different quantiles distribution by panel quantiles regression estimated at low to high quantiles distribution, further complemented with panel causality test and panel innovation accounting matrix.

\section{Data and Methodology}

The study utilized four broad measures of technology innovation to construct a single composite technology index, including computer communications as a percentage of commercial service exports (denoted by TINOV_1), fixed telephone subscriptions per 100 people (indicated by TINOV_2), ICT service exports as a percentage of service exports (marked by TINOV_3), and internet users as a percentage of the population (denoted by TINOV_4). The data of

Table II. Recent Literature on Technology Innovation and Environmental Sustainability

\begin{tabular}{|c|c|c|c|c|c|}
\hline Authors & Time Period & Country & $\begin{array}{l}\text { Technology } \\
\text { Innovation } \\
\text { Factors }\end{array}$ & $\begin{array}{l}\text { Environmental / } \\
\text { Other Factors }\end{array}$ & Results \\
\hline $\begin{array}{l}\text { Chen and } \\
\text { Lei (2018) }\end{array}$ & $1980-2014$ & 30 countries & $\begin{array}{l}\text { Total patent } \\
\text { applications }\end{array}$ & $\begin{array}{l}\text { Carbon } \\
\text { emissions, } \\
\text { renewable energy } \\
\text { consumption }\end{array}$ & $\begin{array}{l}\text { Technological innovations } \\
\text { support to achieve carbon } \\
\text { mitigation agenda through } \\
\text { attained energy efficiency level. }\end{array}$ \\
\hline $\begin{array}{l}\text { Zhang } \\
\text { et al. } \\
(2018)\end{array}$ & 2008-2015 & $\begin{array}{l}31 \text { Chinese } \\
\text { provincial } \\
\text { data }\end{array}$ & $\begin{array}{l}\text { Number of } \\
\text { patent } \\
\text { applications }\end{array}$ & $\begin{array}{l}\text { R\&D investment } \\
\text { and GDP per } \\
\text { capita }\end{array}$ & $\begin{array}{l}\text { R\&D spending and continued } \\
\text { economic growth are considerec } \\
\text { the main factors to increase } \\
\text { technology investment, } \\
\text { which support the country's } \\
\text { sustainability agenda. }\end{array}$ \\
\hline $\begin{array}{l}\text { Xue } \\
\text { et al. } \\
(2018)\end{array}$ & $\begin{array}{l}\text { Primary / } \\
\text { questionnaire } \\
\text { research }\end{array}$ & $\begin{array}{l}\text { A } \\
\text { qualitative } \\
\text { survey from } \\
\text { some major } \\
\text { cities of } \\
\text { China }\end{array}$ & $\begin{array}{l}\text { Technology } \\
\text { patents in the } \\
\text { process of } \\
\text { Information and } \\
\text { Communication } \\
\text { Technologies } \\
\text { (ICTs) }\end{array}$ & $\begin{array}{l}\text { ICTs network } \\
\text { size, density, } \\
\text { emotional } \\
\text { attachment, } \\
\text { signal strength, } \\
\text { relationship, etc. }\end{array}$ & $\begin{array}{l}\text { ICTs would be able to build } \\
\text { new green construction methods } \\
\text { through promoting innovation. }\end{array}$ \\
\hline $\begin{array}{l}\text { Li et al. } \\
\text { (2018) }\end{array}$ & $\begin{array}{l}\text { Bibliometric } \\
\text { research }\end{array}$ & $\begin{array}{l}\text { Global } \\
\text { bibliometric } \\
\text { studies } \\
\text { count }\end{array}$ & $\begin{array}{l}\text { Disruptive } \\
\text { technology } \\
\text { and emerging } \\
\text { technology }\end{array}$ & $\begin{array}{l}\text { Co-citation and } \\
\text { Bibliographic } \\
\text { coupling. }\end{array}$ & $\begin{array}{l}\text { It is confirmed the link between } \\
\text { disruptive and emerging } \\
\text { technology through innovation. }\end{array}$ \\
\hline $\begin{array}{l}\text { Shubbak } \\
\text { (2019) }\end{array}$ & $1995-2017$ & China & $\begin{array}{l}\text { Photovoltaic } \\
\text { technology, R\&D } \\
\text { expenditures, } \\
\text { patents, etc. }\end{array}$ & $\begin{array}{l}\text { PV installations, } \\
\text { trade disputes, } \\
\text { and carbon } \\
\text { emissions }\end{array}$ & $\begin{array}{l}\text { The role of government policies } \\
\text { assists in PV installation to } \\
\text { progress towards environmental } \\
\text { sustainability. }\end{array}$ \\
\hline
\end{tabular}


Table II. Recent Literature on Technology Innovation and Environmental Sustainability

\begin{tabular}{|c|c|c|c|c|c|}
\hline Authors & Time Period & Country & $\begin{array}{l}\text { Technology } \\
\text { Innovation } \\
\text { Factors }\end{array}$ & $\begin{array}{l}\text { Environmental / } \\
\text { Other Factors }\end{array}$ & Results \\
\hline $\begin{array}{l}\text { Wu et al. } \\
\text { (2019) }\end{array}$ & $1992-2010$ & $\begin{array}{l}735 \text { Chinese } \\
\text { emerging } \\
\text { companies }\end{array}$ & $\begin{array}{l}\text { Total number } \\
\text { of patents }\end{array}$ & $\begin{array}{l}\text { Market maturity, } \\
\text { cultural distance, } \\
\text { and absorptive } \\
\text { capability }\end{array}$ & $\begin{array}{l}\text { Market maturity, intellectual } \\
\text { property rights of foreign } \\
\text { markets protection, cultural } \\
\text { space, and absorptive capacity } \\
\text { to enter emerging companies } \\
\text { increase technology innovation } \\
\text { performance. }\end{array}$ \\
\hline $\begin{array}{l}\text { Aldakhil } \\
\text { et al. } \\
(2019)\end{array}$ & $1975-2016$ & South Asia & ICTs & $\begin{array}{l}\text { Carbon-fossil fuel } \\
\text { emissions, R\&D } \\
\text { expenditures, FDI } \\
\text { inflows, GDP per } \\
\text { capita, etc. }\end{array}$ & $\begin{array}{l}\text { ICTs have a positive impact on } \\
\text { environmental quality by limiting } \\
\text { carbon-fossil emissions through } \\
\text { higher R\&D spending. }\end{array}$ \\
\hline $\begin{array}{l}\text { Batool } \\
\text { et al. } \\
(2019)\end{array}$ & $1973-2016$ & South Korea & ICTs & $\begin{array}{l}\text { Carbon } \\
\text { emissions, GDP } \\
\text { per capita, and } \\
\text { energy demand. }\end{array}$ & $\begin{array}{l}\text { ICTs have a positive link to } \\
\text { mitigate carbon emissions by the } \\
\text { synergetic effect of continued } \\
\text { economic growth and level of } \\
\text { energy efficiency. }\end{array}$ \\
\hline $\begin{array}{l}\text { Shahbaz } \\
\text { et al. } \\
(2018)\end{array}$ & $1955-2016$ & France & $\begin{array}{l}\text { Energy } \\
\text { innovations } \\
\text { measured by } \\
\text { R\&D spending } \\
\text { in the energy } \\
\text { sector }\end{array}$ & $\begin{array}{l}\text { Carbon } \\
\text { emissions, } \\
\text { financial } \\
\text { development, } \\
\text { energy demand, } \\
\text { and economic } \\
\text { growth }\end{array}$ & $\begin{array}{l}\text { Energy innovation and financial } \\
\text { development decrease carbon } \\
\text { emissions while FDI inflows } \\
\text { increase carbon emissions. }\end{array}$ \\
\hline $\begin{array}{l}\text { Al Mamun } \\
\text { et al. } \\
(2018)\end{array}$ & $1980-2015$ & $\begin{array}{l}25 \text { OECD } \\
\text { countries }\end{array}$ & $\begin{array}{l}\text { R\&D spending } \\
\text { in the energy } \\
\text { sector }\end{array}$ & $\begin{array}{l}\text { Financial } \\
\text { development, } \\
\text { carbon emissions, } \\
\text { and renewable } \\
\text { energy demand. }\end{array}$ & $\begin{array}{l}\text { Financial development and } \\
\text { renewable energy improve } \\
\text { innovation across countries. }\end{array}$ \\
\hline $\begin{array}{l}\text { Ahmed } \\
\text { and Ozturk } \\
(2018)\end{array}$ & $1985-2013$ & China & $\begin{array}{l}\text { Total number } \\
\text { of patent } \\
\text { applications in } \\
\text { the energy sector }\end{array}$ & $\begin{array}{l}\text { Carbon emissions } \\
\text { and energy } \\
\text { intensity. }\end{array}$ & $\begin{array}{l}\text { Technological innovations } \\
\text { increase energy intensity to } \\
\text { reduce carbon emissions. }\end{array}$ \\
\hline
\end{tabular}

technology innovation factors from TINOV_1 to TINOV_4 is obtained from the World Bank (2019) data base, for the period 1995-2018.

Principal Component Analysis (PCA) is used for this purpose, shown in Table SI in the supplementary material. Two factors, out of four elements, have eigenvalues larger than unity, i.e., 1.619 and 1.375 , while the remaining two factors have eigenvalues of
0.601 and 0.403 , respectively. A modest difference was found between factors one and two, i.e., 0.244, while the greater difference was found between factors two and three, i.e., 0.773. The least difference was found between factors three and four, which is about 0.198 . The eigenvalue difference clearly shows that the variation among two and three factors is large. Thus, factors one and two are used to construct 
the TINDEX in the study. Further, the eigenvectors loading shows the four principal components (PC), and $\mathrm{PC} 1$ has a greater sum value, i.e., 1.96, followed by PC4 (0.322), PC2 (0.217), followed by PC3 with minimum additive eigenvalue loading of 0.028 . Thus, $\mathrm{PC} 1$ is used to construct a single composite index for technology innovation. Finally, the correlation matrix between the technology index shows that TINOV_1 is positively correlated with the rest of the technology innovation factors, i.e., TINOV_2, TINOV_3, and TINOV_4, whereas there is a negative correlation is found between TINOV_2 and TINOV_3. Aweak correlation was found between TINOV 3 and TINOV 4 .
Thus, TINOV 1 has a greater variation among the correlated technology factors, which exhibits a strong basis of TINDEX by utilizing the appropriate technical aspects. Figure 1 shows the eigenvalue plots and orthonormal loadings.

Figure 1 illustrates that orthonormal loadings divided the technology factors into the two sub-components, the first component has a greater percentage variance $(40.5 \%)$ while the second component exhibits $34.4 \%$ variance of the composite technology index. The remaining $25.1 \%$ variance is due to unseen components of other possible factors. Followed by orthonormal loadings, the scree plots also indicate the
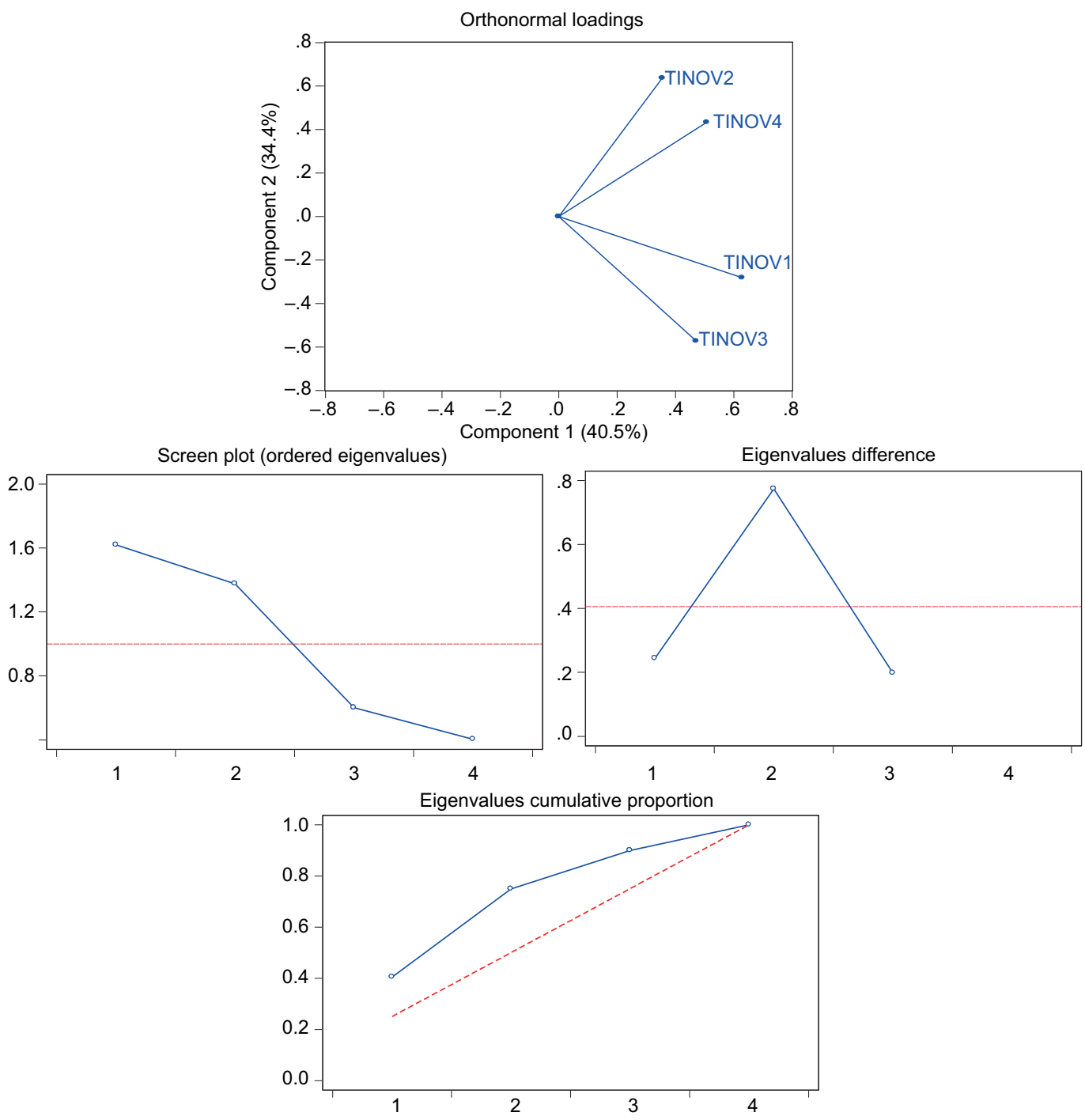

Fig. 1. Eigenvalue Plots and Orthonormal Loadings. 
two main factors with eigenvalues larger than unit, and the substantial peak visible in the eigenvalue difference shows that the difference of variation is quite high in the second and third technology factors. Finally, the cumulative eigenvalue proportion shows the consistent trend towards one. This exercise gives a sound composite technology index (TINDEX) with a minimum value of -4.692 and a maximum value of 1.611 with a median value of 0.128 .

The study used additional variables such as, air transport freight in million ton-km (denoted by ATF), freight pricing as CPI percentage (denoted by FPRICE), freight revenue per million ton $-\mathrm{km}$ in US\$ (denoted by FREV) [estimated by the authors as $($ ATF $\times$ FPRICE/100) $\times$ Quantity of cargo/shipment], foreign direct investment inflows in current US\$ (denoted by FDI), insurance and financial services as percentage of commercial service exports (denoted by IFS), and greenhouse gas emissions in kt of $\mathrm{CO} 2$ equivalent (denoted by GHG). All of the data is taken from the World Bank (2019) database from 1995 through 2018. Missing information is filled by subsequent and preceding values of the respective variables where required.

The study followed the scholarly work of Ahmed and Ozturk (2018), Hishan et al. (2019), and Al Mamun et al. (2018) to estimate the dynamic interaction among technology innovation, freight pricing, and GHG emissions in a panel of 39 R\&D economies. Ahmed and Ozturk (2018) concluded that technology innovation is desirable to set up renewable energy projects to assess the clean energy reforms, while Hishan et al. (2019) argued that access to technologies would be achieved environmental sustainability agenda via limiting the carbon emissions. Al Mamun et al. (2018) found that synergies in financial development and innovations would help improve the cleaner energy resources to enhance environmental quality. The following linear model is proposed based on the cited studies:

$$
\begin{aligned}
& G H G_{i t}=\alpha_{0}+\alpha_{1} \text { TINDEX }_{i t}+\alpha_{2} \text { ATF }_{i t}+ \\
& \alpha_{3} \text { FPRICE }_{i t}+\alpha_{4} \text { FREV }_{i t}+\alpha_{5} F D I_{i t}+\alpha_{6} I F S_{i t}+\varepsilon_{i t}
\end{aligned}
$$

where GHG corresponds to GHG emissions, TINDEX is the technology innovation index, ATF shows air transport freight, FPRICE shows freight pricing, FREV shows freight revenues, FDI shows FDI inflows, IFS correspond to insurance and financial services. The subscripts ' $i$ ' indicate each of the 39 countries and ' $t$ ' the years from 1995-2018; and, finally, $\varepsilon$ corresponds to the error term.

Equation (1) shows that the environmental sustainability agenda (expressed by GHG emissions) is influenced by technology innovation, air transportation freight, air freight pricing, air freight revenues, FDI inflows, and insurance and financial services a panel of 39 R\&D economies. The sign of the coefficient relating GHG emissions, and the technology innovation index is expected to be negative $\left(\alpha_{1}<0\right)$, since technology will result in decreased emissions. The relationship between air transportation cargo and GHG emissions is expected to be positive $\left(\alpha_{2}>0\right)$ since increase air freight increases GHG emissions, resulting in negative impact on climate.

The R\&D economies are investing in energy conservation and environmental resources and complement the Paris Agreement through carbon pricing (Sarkodie and Ozturk, 2020). The carbon tax and emissions-cap modeling are used as sustainable policy instruments to mitigate GHG emissions. Given this scenario, this study used air freight pricing to impose a tax on unsustainable cargo activities to raise sufficient freight revenue to reinvest in environmentally sustainable activities. The sign of the coefficients for the interventions of air freight pricing and air freight revenues is expected to be negative with GHG emissions $\left(\alpha_{3}<0\right.$ and $\left.\alpha 4<0\right)$. The study used the two broad measures of institutional factors in the form of FDI inflows and insurance and financial services to assess their role in the environmental sustainability agenda across a panel of countries. It is expected that institutional performance would perform better under the technology innovation factor, if and only if the air freight pricing could achieve the desired pollution reduction targets. If this case persists, the impact of FDI inflows and insurance and financial services would be positive (the negative relationship between them), and it would decline GHG emissions $(\alpha 5<0$ and $\alpha 6<0)$. On the other hand, if the air freight pricing strategy fails to achieve the assigned pollution targets, it will negatively impact climate change exacerbating GHG emissions across countries. Thus, it will confine the findings of the 'pollution haven' hypothesis. Therefore, differential impacts would be expected between institutional factors and mitigating GHG emissions given the different signs of the 
coefficients (i.e., $\alpha 5>0$ and $\alpha 6>0$ ). Figure 2 shows the research framework, coupled with the research hypothesis of the study.

Figure 2 shows that technological innovation, freight pricing, and institutional factors will have a differential impact on GHG emissions. Technology leads to increased economic activity and environmental deterioration. However, after reaching some maturity stage, carbon pricing would help generate sufficient revenues to reinvest in the ecological protection agenda and increased investment in $R \& D$, sustainable logistics freight activities, and responsible consumption and production. Further, it may lead to bidirectional linkages between the technological factors, air transportation freight mechanism, institutional factors, and environmental sustainability agenda. Thus, the study hypothesized the following statements for analysis:

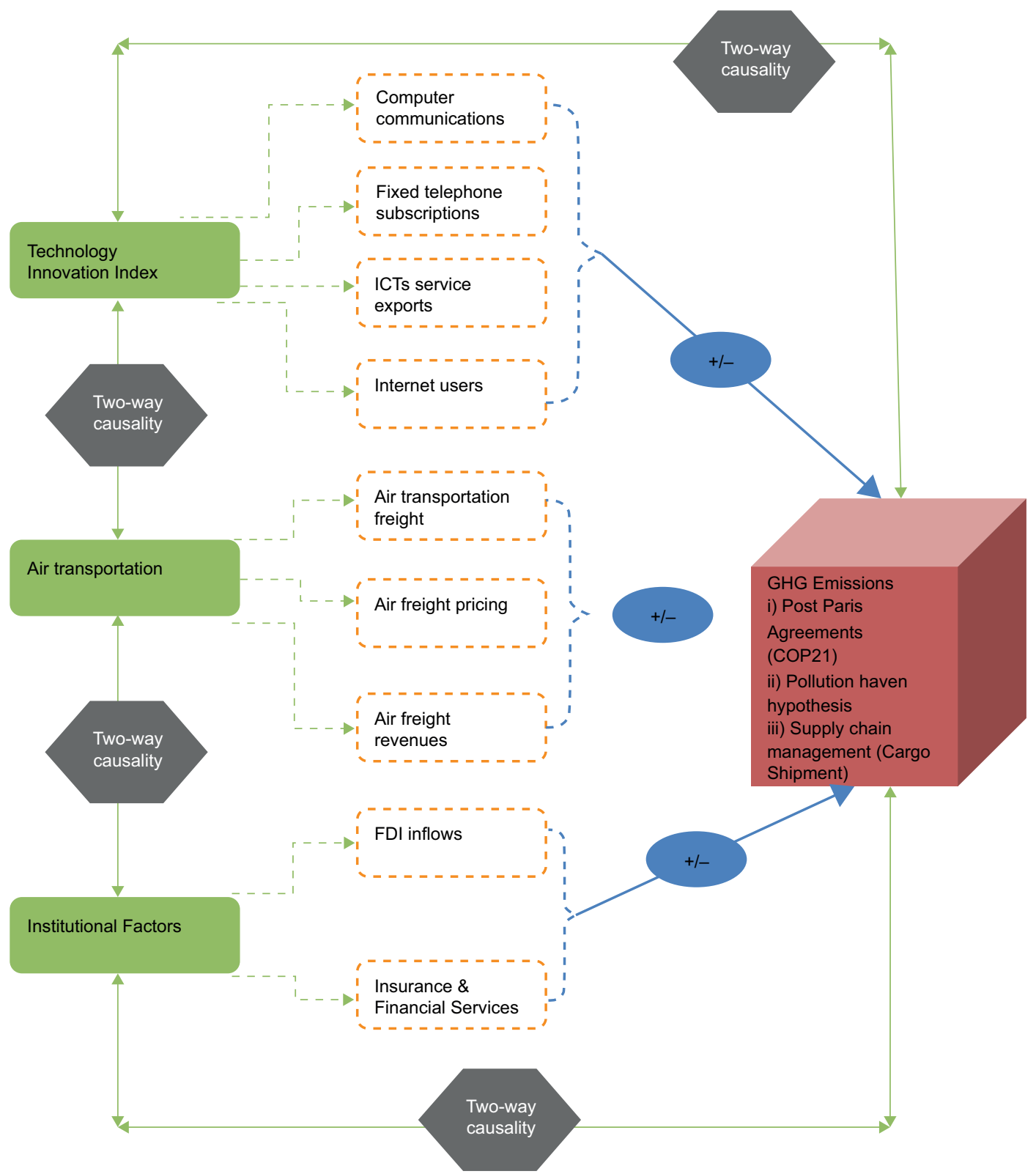

Fig. 2. Research Framework of the Study. 
H1: Technological innovations will positively impact environmental quality in the form of a reduction of $G H G$ emissions.

H2: Airfreight pricing and air freight revenues will decrease GHG emissions to support the COP21 Paris agreement, and

H3: Institutional factors will positively work under technological innovations and air freight mechanisms to lessen GHG emissions.

These hypotheses are evaluated using sophisticated panel econometric modeling, including panel quantiles regression, panel Dumitrescu-Hurlin (DH) causality test, and innovation accounting matrix.

Two generations of panel unit root testing are presented, differentiated in Table III for clear understanding.

The first-generation tests assume no cross-sectional dependency (CSD) among the cross-sectional identifiers; thus, this test is based on a homogenous assumption. In contrast, the second-generation tests find the CSD among the selected cross-section identifiers. Therefore, this test is based upon heterogeneous assumptions. The study used the first line testing framework to validate the homogenous assumptions. In contrast, after analyzing the unit root test results, once the candidate variables exhibit stationarity, the study moves to the panel quantile regression that accounts for unobserved heterogeneity and heterogeneous covariate effects. However, on the other hand, if the candidate variables are non-stationary, then first-generation cointegration estimates are used.
The panel quantiles regression works under the distributional pattern in the number of different quantiles from $10 \%$ to $90 \%$, which handle the unobserved heterogeneity in the given model (Kato et al. 2012). Let us consider the model:

$(y)_{i, t}=x_{i, t}+v_{i}+u_{i, t}$

where ' $y$ ' corresponds to a response variable, ' $\mathrm{x}$ ' indicates the list of regressors, ' $v$ ' corresponds to fixed-effect estimators, and $\mathrm{u}$ indicates the white noise term.

The quantile specification of the parameters to minimize quantile function is:

$$
\begin{aligned}
& Q_{G H G_{i, t}}[\tau \perp(\text { TINDEX }, A T F, F P R I C E, \\
& \left.F R E V, F D I, I F S)_{i, t}\right]=v_{i}+x_{i, t}^{T} \beta(\tau), \quad T \subseteq(0,1)
\end{aligned}
$$

Further, the panel DH causality test (Dumitrescu-Hurlin, 2012) is utilized to assess whether the stated variables have some cause-effect relationship between them. Eqn. 4 is formulated at the cross-section ' $i$ ' concerning some given period ' $t$ ', as:

$y_{i t}=c_{i}+\rho_{i, 1} y_{i, t-1}+\rho_{i, 2} y_{i, t-2}+\ldots . .+$
$\rho_{i, p} y_{i, t-p}+v_{i, 1} x_{i, t-1}+v_{i, 2} x_{i, t-2}+\ldots . .+v_{i, p} x_{i, t-p}+\varepsilon_{i, t}$

The null and alternative hypotheses are presented below:

$H_{0}: \Psi k \geq 1$ and $\psi i, \beta_{i, k}=0 ; x_{i, t}$ does not homogenous cause $y_{i, t}, \psi i$ where, $\Psi$ shows $\mathrm{w}$-statistics, ' $k$ ' shows z-bar statistics, $\beta$ shows intercept coefficient, $x$ shows

\begin{tabular}{|c|c|c|c|}
\hline \multicolumn{2}{|c|}{ First Generation Panel Testing Framework } & \multicolumn{2}{|c|}{ Second Generation Panel Testing Framework } \\
\hline \multicolumn{4}{|c|}{ I. Panel Unit Root Tests } \\
\hline Im, Pesaran, and Shin test & Levin, Lin, and Chu test & Pesaran test & Bai and $\mathrm{Ng}$ test \\
\hline Breitung test & \multirow{2}{*}{ Hadri test } & Chang test & \multirow{2}{*}{ Moon and Perron test } \\
\hline Maddala et al. test & & Harris et al. test & \\
\hline \multicolumn{4}{|c|}{ II. Panel Cointegration Tests } \\
\hline $\begin{array}{l}\text { Pedroni residual } \\
\text { cointegration }\end{array}$ & $\begin{array}{l}\text { Kao residual } \\
\text { cointegration }\end{array}$ & $\begin{array}{l}\text { Westerlund } \\
\text { cointegration }\end{array}$ & $\begin{array}{l}\text { Westerlund and } \\
\text { Edgerton cointegration }\end{array}$ \\
\hline
\end{tabular}

Table III. Generations of Panel Unit Root Testing Framework.

Source: Sharif et al. (2019), Jardón et al. (2017) and Yalçınkaya et al. (2017). 
explanatory variables, ' $i$ ' shows cross-section, and ' $t$ ' shows time period.

$H_{A}: \Psi k \geq 1$ and $\psi i, \beta_{i, k} \neq 0 ; x_{i, t}$ does homogenous cause $y_{i, t}, \psi i$ where, $\Psi$ shows $w$-statistics, ' $k$ ' shows z-bar statistics, $\beta$ shows intercept coefficient, ' $y$ ' shows response variable, $x$ shows explanatory variables, ' $i$ ' shows cross-section, and 't' shows time period.

The panel DH causality test (Dumitrescu-Hurlin, 2012) test is used in this study based upon semi-asymptotic distributions. The cross-section identifiers are larger than the period; thus, it would help policymaking that further leads to inter-temporal setting over a time horizon. The innovation accounting matrix, including impulse response function (IRF) and variance decomposition analysis (VDA), is further used for forecasting VAR modeling.

\section{Results and Discussion}

Table IV shows the candidate variables' descriptive statistics and that there are four technology innovation factors, including computer communications (TINOV_1) that have a mean value of $35.327 \%$ of commercial service exports with a maximum value of $75.445 \%$ and a minimum value of $0.469 \%$. The remaining technology factors, i.e., fixed telephone subscriptions (TINOV_2), ICT service exports (TINOV_3), and internet users (TINOV_4) have a mean value of 30.859 per 100 people, $6778 \%$ of service exports, and $38.811 \%$ of the population, respectively. The mean value of air transport freight, freight pricing, and freight revenues are 2708 million ton-km, 7.829\%, and US $\$ 9,26,466.3$, respectively.
The FDI inflows have a maximum value of $5.09 \mathrm{E}+11$ with a mean value of $2.68 \mathrm{E}+10$ and positively skewed distribution and high kurtosis value. The insurance and financial services and GHG emissions have a mean value of $5.950 \%$ of commercial service exports and $909930.1 \mathrm{kt}$ of $\mathrm{CO} 2$ equivalent.

Table V shows the summary of panel unit roots and found that except ATF, the remaining variables are level stationary while ATF is differenced stationary as per LLC and PP estimates. In another panel unit root estimates, ATF and TINDEX are first differenced stationary while the remaining variables are level stationary as per IPS estimates. Finally, except TINDEX, the remaining variables are level stationery,

Table V. Panel Unit Roots Estimates.

\begin{tabular}{lcccc}
\hline Variables & LLC & IPS & ADF & PP \\
\hline ATF & 0.349 & 1.044 & $98.531^{* * *}$ & 84.278 \\
FDI & $-3.302^{*}$ & $-3.677^{*}$ & $123.951^{*}$ & $200.451^{*}$ \\
FPRICE & $-7.149^{*}$ & $-10.302^{*}$ & $263.239^{*}$ & $776.950^{*}$ \\
FREV & $-2.563^{*}$ & $-4.985^{*}$ & $171.835^{*}$ & $496.812^{*}$ \\
GHG & $-4.383^{*}$ & $-2.845^{*}$ & $115.446^{*}$ & $153.331^{*}$ \\
IFS & $-2.424^{*}$ & $-2.524^{*}$ & $109.952^{*}$ & $169.807^{*}$ \\
TINDEX & $-4.459^{*}$ & -0.652 & 89.855 & $130.739^{*}$ \\
\hline
\end{tabular}

First Difference

\begin{tabular}{lllll}
\hline$\triangle$ ATF & $-11.038^{*}$ & $-13.040^{*}$ & $319.326^{*}$ & $675.940^{*}$ \\
$\Delta$ FDI & $-15.168^{*}$ & $-18.159^{*}$ & $445.651^{*}$ & $1801.83^{*}$ \\
$\Delta$ FPRICE & $-18.318^{*}$ & $-22.238^{*}$ & $566.270^{*}$ & $2382.85^{*}$ \\
$\Delta$ FREV & $-18.871^{*}$ & $-21.239^{*}$ & $538.602^{*}$ & $1695.67^{*}$ \\
$\Delta$ GHG & $-10.367^{*}$ & $-13.582^{*}$ & $337.058^{*}$ & $1313.58^{*}$ \\
$\Delta$ IFS & $-12.505^{*}$ & $-16.823^{*}$ & $412.168^{*}$ & $1176.31^{*}$ \\
$\Delta$ TINDEX & $-5.922^{*}$ & $-9.230^{*}$ & $228.071^{*}$ & $506.425^{*}$ \\
\hline
\end{tabular}

Note: $*$ and $* * *$ shows a $1 \%$ and $10 \%$ level of significance.

Table IV. Descriptive Statistics.

\begin{tabular}{lcccccccccc}
\hline Methods & ATF & FPRICE & FREV & TINOV_1 & TINOV_2 & TINOV_3 & TINOV_4 & FDI & IFS & GHG \\
\hline Mean & 2708.269 & 7.829 & 926466.3 & 35.327 & 30.859 & 6.778 & 38.811 & $2.68 \mathrm{E}+10$ & 5.950 & 909930.1 \\
Maximum & 41591.55 & 709.346 & 59335554 & 75.445 & 74.742 & 52.088 & 94.620 & $5.09 \mathrm{E}+11$ & 41.318 & 12064260 \\
Minimum & 0.418 & -1.736 & -4379784 & 0.469 & 1.247 & 0.291 & 0.000123 & $-6.77 \mathrm{E}+10$ & -1.462 & 18869.70 \\
Std. Dev. & 5952.352 & 31.121 & 5073669 & 16.475 & 18.658 & 7.475 & 30.098 & $5.51 \mathrm{E}+10$ & 7.120 & 1795114 \\
Skewness & 4.563 & 15.542 & 7.754 & 0.045 & 0.182 & 3.520 & 0.171 & 4.168 & 2.641 & 3.895 \\
Kurtosis & 25.933 & 308.315 & 68.92 & 2.455 & 1.871 & 17.778 & 1.594 & 24.803 & 10.674 & 20.030 \\
\hline
\end{tabular}

Note: ATF shows air transport freight; FPRICE shows freight pricing, FREV shows freight revenues, TINOV_1 shows Computer communications, TINOV_2 shows fixed telephone subscriptions, TNOV_3 shows ICT service exports, TINOV_4 shows internet users, FDI shows FDI inflows, IFS show insurance and financial services, and GHG shows GHG emissions. 
while TINDEX is first differenced stationary. Hence, we may generally conclude that all variables are level stationary; thus, we proceed towards panel quantile regression.

Table VI shows the panel quantiles estimates and found that technology innovation index has a negative relationship with GHG emissions at different quantiles distribution, which implies that technology innovation is helpful in reducing GHG emissions and promoting a sustainability agenda. Su and Moaniba (2017) concluded that advancements in technology innovation result in mitigating global carbon emissions in high carbon-emitting countries, which need increased public funding to conserve the natural environment through sustainable policy efforts. Huang et al. (2016) found that additive manufacturing technologies help achieve energy efficiency to mitigate GHG emissions. Zhang et al. (2016) suggested that global innovators should increase the market share of energy-intensive commodities to advance in global technologies that would help combat climate change vulnerabilities and achieve energy efficiency through knowledge diffusion across the globe. Atuonwu et al. (2018) argued that the importance of technology innovation in food processing and preservation is highly desirable to achieve energy efficiency leading to the reduction of GHG emissions. Technology advancement improves biological activities and nutritional quality that recover hygiene and public health for sustainable food production. Park (2018) found that eco-environmental policies are imperative to sustained long-term goals that would help mitigate carbon emissions by reconfiguring economic structure. Grubler et al. (2018) concluded that energy transformation and renewable energy restructuring are important to limit global average temperature to less than $2^{\circ} \mathrm{C}$ that would escalate economic activity and sustainable development. Nerini et al. (2019) concluded that R\&D spending, innovation, governance, and social innovation sustain economic and environmental policies to limit high carbon emissions to combat climate change.

Figure 3 shows the panel quantiles process estimates. There is a positive relationship between air transport freight and GHG emissions at different quantiles distribution, which implies that logistics activities are based upon unsustainable fuel consumption; hence it negatively impacts the natural

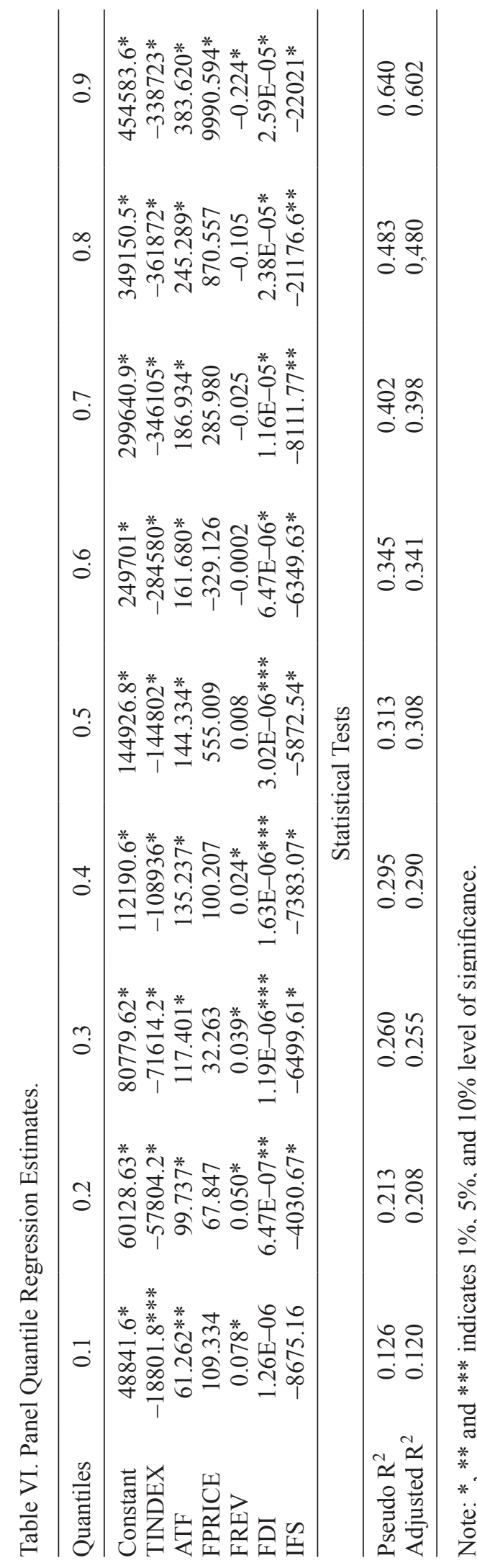


Quantile process estimates
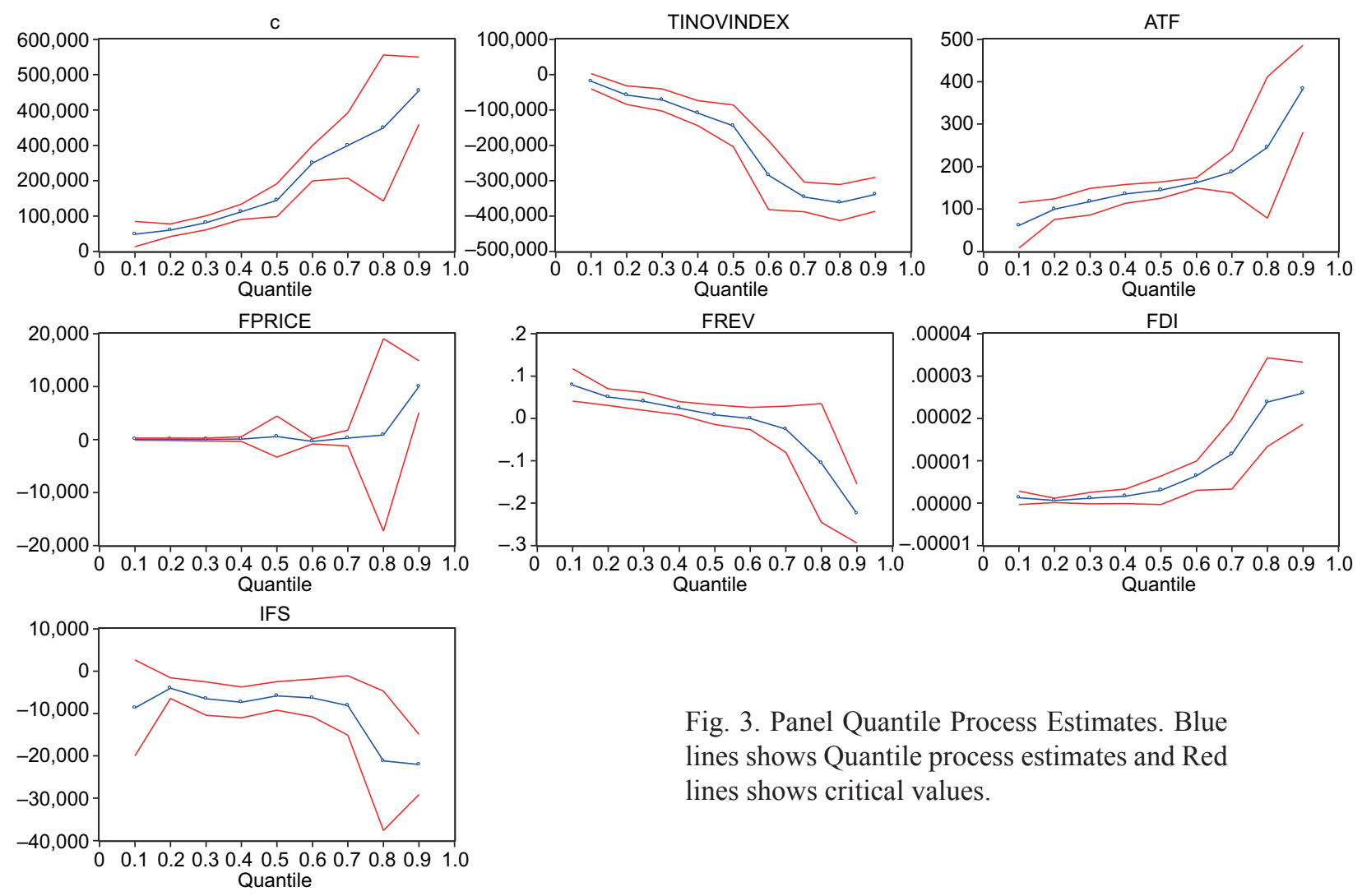

Fig. 3. Panel Quantile Process Estimates. Blue lines shows Quantile process estimates and Red lines shows critical values.

environment in the form of high GHG emissions. The post-Paris agreement (COP21) is highly affected by unsustainable logistics activities, and thus, there is an increased need to use renewable fuels in logistics activities. Hao et al. (2015) argued that air transportation freight has a substantial impact on energy demand, largely responsible for escalating global GHG emissions. Sustainable policy options should be desirable to mitigate environmental problems from logistics activities. According to Van Fan et al. (2018), the transportation industry is to blame for rising GHG emissions, with severe issues arising when products' loaded capacity exceeds its allocated capacity, resulting in emissions. Its a reaction to a logistics service provider's request to track the loaded power of items to reduce air pollution. Goetz and Alexander (2019) suggested several ways through which climate action plans (CAPs) could be executed efficiently by seeking information from freight transportation data and found that GHG emissions could be lowered by reducing the vehicle miles traveled, using city-owned vehicle fleets, electrified transportation and alternatively shift fuels from non-renewable to renewable. Thus, these CAPs would include sustainable policies to decarbonize logistics through smart freight movement. Pizzol (2019) emphasized the need to use intermodal transportation that could prevent emissions through reducing traffic from high to low emissions vehicles. Thus, sea-route freight could be shifted to road routes, while for other intermodal transportation the use of ferries in cargo transportation would help reduce emissions, depending on the size and fuel used. Thus, the transportation shipment could be made in sustainable modes via shifting of goods movement from intermodal transportation.

The relationship between air freight pricing and GHG emissions is less evident as in the $90^{\text {th }}$ quantiles this relationship is positive (Fig. 3), indicating less efficient freight pricing in mitigation of $\mathrm{GHG}$ emissions across countries. The results evidence that freight pricing needs more sustainable options to impose optimum freight tariffs to limit GHG emissions. 
Gupta (2016) argued that the willingness-to-pay for environmental protection shows a greater concern for mitigating carbon emissions in green development portfolios. For this purpose, carbon pricing in the transportation sector would be a desirable strategy to reduce environmental risks through the contingent valuation method. Santos (2017) suggested the need to impose fuel taxes on the different modes of transportation that reduce negative environmental externalities, and it is desirable to emphasize payas-you-drive insurance schemes for safe movement. Avetisyan (2018) found that the transportation sector contributed a maximum share of GHG emissions through ground transportation, air, and water transport. Global carbon pricing is considered a highly sustainable policy instrument that improves transportation exports and lessens global emissions. Zahedi et al. (2019) generalized the field survey findings of willingness-to-pay for environmental protection through carbon tax imposition on the transport sector. They found positive remarks about the imposition of transportation taxes to reduce carbon emissions stock to achieve sustainable development agendas. Gupta et al. (2019) were generally in favor of the imposition of carbon taxes on the transportation sector. They found the different emissions reduction targets by diverse carbon tariffs, thus imposing an appropriate pricing mechanism on getting sustainable payoffs and achieving greater carbon reduction targets.

The relationship between air freight revenues and GHG emissions is positive (negative impact) at $10^{\text {th }}$ percentiles to $40^{\text {th }}$ percentiles; however, at $90^{\text {th }}$ percentiles, air freight revenues have a negative relationship (positive effect) with GHG emissions that confirmed the positivity of air fright revenues to mitigate emissions. There is a positive relationship between FDI inflows and GHG emissions, which established the 'pollution haven' hypothesis across countries. There is a need to regulate environmental policies by limiting GHG emissions, which requires sustainable policy options for achieving green development by advancement in cleaner energy. There is a negative relationship between insurance and financial services and GHG emissions, which implies that green financing improves logistics performance, utilizing renewable fuels to gear economic performance for shipment. Michaelowa (2015) discussed the importance of sustainable insurance policies to reduce the risk of climate change in line with the Paris Agreement and the Kyoto protocol. Naz et al. (2019) presented a long-term policy channel through which carbon emissions stock could be reduced by achieving energy efficiency by cleaner energy production, launching green financial projects to improve air quality, and continued economic growth responsible production and consumption. Thus, the flair of socio-economic and environmental policies is desirable to attain sustainable development agenda with national integrated green systems. Sarkodie and Strezov (2019) emphasized the need to improve global partnerships to delimit high mass carbon emissions by adopting sustainable policy options. The advancement in the cleaner production agen$\mathrm{da}$, utilization of renewable energy projects, fossil fuel storage, and biomass production are the few complementary examples that would be placed in the carbon mitigation agenda for global prosperity. Hassan et al. (2019) generally favor mitigation carbon emissions based on aviation transportation through the reduction of diesel oil and replaced it with renewable fuels. Shouket et al. (2019) designed a green vehicle framework and emphasized the need to adopt some re-corrective measures, including the use of smart applications in travel services, stringent environmental regulations, population control, and improve transportation infrastructure. All these measures would reduce carbon emissions and achieve green development agendas with sustainable modes of transportation.

Table VII shows the slope and symmetric quantiles estimates and confirmed no such heteroskedasticity problem as slope equality and symmetric quantiles estimates fall in the $5 \%$ critical region. Thus, the panel quantile estimates are reliable and valid.

Table SII presents the causality estimates as supplementary material. It is found that there is bidirectional causality running between fright price and GHG emissions, while there is a unidirectional causality running from insurance and financial services (IFS) to GHG emissions, from fright price to IFS, and from FDI to IFS. The one-way linkage runs from GHG to the technology innovation index, from GHG emissions to FDI inflows, and from ATF to FDI inflows. Besides, the feedback relationship found between i) ATF to TINOVINDEX, ii) FPRICE to TINOVINDEX, iii) FREV to TINOVINDEX, 
Table VII. Slope and Symmetric Quantiles Test Estimates.

\begin{tabular}{lccc}
\hline Methods & $\begin{array}{c}\text { Chi-Square } \\
\text { Statistic }\end{array}$ & $\begin{array}{c}\text { Ch-square degree } \\
\text { of freedom }\end{array}$ & $\begin{array}{c}\text { Probability } \\
\text { value }\end{array}$ \\
\hline $\begin{array}{l}\text { Quantile Slope } \\
\text { Equality - Wald Test }\end{array}$ & 837.109 & 18 & 0.000 \\
\hline $\begin{array}{l}\text { Symmetric } \\
\text { Quantiles - Wald Test }\end{array}$ & 316.800 & 14 & 0.000 \\
\hline
\end{tabular}

iv) FDI to TINOVINDEX, v) FREV to ATF, and vi) FDI to FREV.

The following results emerged from this exercise:

i) The need for a technology innovation index is desirable to mitigate $\mathrm{GHG}$ emissions.

ii) The imposition of freight prices is desirable to promote sustainable logistics activities.

iii) The reinvestment of freight revenues into cleaner production technologies is desirable to achieve the environmental sustainability agenda.

iv) Transportation freight contributes to the growth of FDI inflows at the expense of increased GHG emissions.

v) Logistic activities based upon green insurance and financial services can reduce $\mathrm{GHG}$ emissions.

Table VIII shows the Impulse Response Function (IRF) estimates, indicating that the technology index has a negative relationship with GHG emissions, which implies that technology innovation will largely reduce GHG emissions through advancement in cleaner production technologies in the next ten years. Further, sustainable logistics activities in the form of shipment, air freight prices, freight revenues, FDI inflows, and green insurance will also decrease GHG emissions over this time horizon. The positive determinant of technology innovation will be freight price while the remaining factors, including $\mathrm{GHG}$ emissions, air transportation freight, freight revenues, FDI inflows, and IFS, will negatively impact on technology innovation index over this time horizon. Other IRF estimates are presented in Table SIII.

The technology innovation index will positively support air transportation freight, while freight prices and freight revenues will negatively impact air transportation freight. In the next decade, there will be a negative association between freight prices and GHG emissions, technology innovation index, FDI inflows, and insurance and financial services,

Table VIII. IRF Estimates for GHG Emissions.

\begin{tabular}{cccccccc}
\hline \multicolumn{7}{c}{ The response of GHG: } \\
\hline Period & GHG & TINOVINDEX & ATF & FPRICE & FREV & FDI & IFS \\
\hline 1 & 234456.2 & 0 & 0 & 0 & 0 & 0 & 0 \\
2 & 159458.7 & -2317.655 & 9742.038 & -9386.730 & -15765.52 & 3211.644 & -629.1388 \\
3 & 190194.1 & -2412.029 & -5712.869 & -12057.68 & -20237.34 & -3468.127 & -1207.644 \\
4 & 185564.4 & -2165.258 & -7166.369 & -15572.39 & -20514.57 & -3040.836 & -1621.616 \\
5 & 193377.9 & -2197.448 & -10832.68 & -17684.09 & -21771.24 & -3417.555 & -1678.556 \\
6 & 196968.5 & -2291.145 & -13445.17 & -19478.11 & -21803.09 & -3170.008 & -1697.907 \\
7 & 202130.0 & -2423.833 & -16001.42 & -20824.92 & -21632.68 & -2850.160 & -1611.961 \\
8 & 206807.5 & -2606.357 & -18356.19 & -21937.72 & -21241.21 & -2417.190 & -1473.782 \\
9 & 211689.9 & -2828.593 & -20702.31 & -22861.67 & -20740.73 & -1963.985 & -1290.380 \\
10 & 216524.3 & -3088.365 & -23026.40 & -23664.91 & -20156.14 & -1482.865 & -1073.105 \\
\hline
\end{tabular}

Source: Author's estimation. 
but a positive relationship between freight prices and freight revenues. Freight revenues will largely be affected by increased GHG emissions, while FDI inflows will exert positive environmental impacts through advancement in technology innovation across countries. The insurance and financial services will positively impact FDI inflows, air transportation freight, and technology innovation index, leading to a decrease in GHG emissions over this time horizon.

Table IX shows the VDA estimates indicating that GHG emissions are largely affected by freight revenues with a variance proportion of $0.919 \%$, followed by freight price $(0.769 \%)$, and air transportation freight $(0.492 \%)$, while the least influenced will be insurance and financial statistics over this time horizon. The innovation shocks to GHG emissions are more significant than the other external shocks, and as a result, the percentage share of freight revenues reached just 0.919 percent. The IRF estimates conclude that technology innovations, air transportation freight, air freight pricing, air freight revenues, FDI inflows, and insurance \& financial services will positively limit GHG emissions across this panel of selected 39 countries. Sustainable technological innovations and air freight pricing would be viable policy instruments to implement in the Post Paris Agreement (COP21) and 2030 agenda of sustainable development. Thus, more concentrated economic and environmental regulatory policies are desirable to reap sustainable payoffs through mutual collaborative global partnerships for shared prosperity. Other VDA estimates are presented in Table SIV.
Freight revenue will largely be affected by the technology innovation index, while the technology innovation index least influences freight price over the next ten years. Freight revenue exerts a greater impact on air transportation freight with a magnitude variance of $20.364 \%$, while freight prices will least influence air freight. GHG emissions have a large impact on freight prices with a magnitude of $0.894 \%$, while FDI inflows will least influence freight prices over this time horizon. Air transportation freight is the main predictor of freight revenues with a magnitude value of $40.559 \%$ while the technology innovation index will least influence freight revenues over the next 10 years. GHG emissions largely impact FDI inflows, while high FDI inflows largely affect insurance and financial statistics over time. The overall results indicate that technological innovations have an enormous role in promoting a country's economic growth through improved logistics activities, smart applications in finance \& insurance services, and technology associated FDI inflows. However, technological innovations need to be sustainable (low-carbon) for compliance with the post-Paris Agreement (COP21) and the 2030 UN agenda on sustainable development.

\section{Conclusions and Policy Implications}

A worldwide partnership and mutual collaboration to limit GHG emissions and maintain the global average temperature less than $2^{\circ} \mathrm{C}$ are highly desirable for sustainable development. Advancements in low-carbon

Table IX. VDA Estimates for GHG Emissions.

\begin{tabular}{ccccccccc}
\hline \multicolumn{7}{c}{ Variance Decomposition of GHG: } \\
\hline Period & SE. & GHG & TINOVINDEX & ATF & FPRICE & FREV & FDI & IFS \\
\hline 1 & 234456.2 & 100 & 0 & 0 & 0 & 0 & 0 & 0 \\
2 & 284331.5 & 99.44628 & 0.006644 & 0.117395 & 0.108988 & 0.307444 & 0.012759 & 0.000490 \\
3 & 342965.1 & 99.10348 & 0.009513 & 0.108433 & 0.198511 & 0.559491 & 0.018995 & 0.001576 \\
4 & 390884.2 & 98.83121 & 0.010392 & 0.117089 & 0.311536 & 0.706162 & 0.020675 & 0.002935 \\
5 & 437160.0 & 98.58239 & 0.010835 & 0.155015 & 0.412710 & 0.812592 & 0.022641 & 0.003821 \\
6 & 480582.2 & 98.37075 & 0.011238 & 0.206539 & 0.505770 & 0.878212 & 0.023085 & 0.004410 \\
7 & 522484.5 & 98.19143 & 0.011660 & 0.268532 & 0.586761 & 0.914423 & 0.022507 & 0.004682 \\
8 & 563066.2 & 98.03768 & 0.012183 & 0.337498 & 0.657027 & 0.929674 & 0.021222 & 0.004717 \\
9 & 602703.2 & 97.90328 & 0.012835 & 0.412552 & 0.717332 & 0.929839 & 0.019585 & 0.004575 \\
10 & 641594.3 & 97.78309 & 0.013644 & 0.492858 & 0.769051 & 0.919223 & 0.017816 & 0.004317 \\
\hline
\end{tabular}

Source: Author's estimation. 
technological innovations provide an option as climate-resilient strategies. This study examines the role of technological innovations and air freight pricing in mitigating GHG emissions in a panel of 39 R\&D economies between 1995 and 2018. For this purpose, the study employed the panel quantile regression technique to obtain parameter estimates at lowest to highest quantile distribution. In addition, the panel Granger causality test and innovation accounting matrix assess the cause-effect relationship and inter-temporal forecast relationship between the variables over the next ten years. The results show that technology innovations and insurance and financial services are the main predictors to reduce GHG emissions whereas, air transportation freight, freight pricing, and FDI inflows increase GHG emissions, evidencing the 'pollution haven' hypothesis across countries. The causality estimates confirmed the feedback relationship between freight pricing and $\mathrm{GHG}$ emissions and technology innovations. Furthermore, causality is two-way between technology innovation and air freight, freight revenues and FDI inflows. Air freight revenues and FDI inflows have a unidirectional relationship with insurance and financial services while GHG emissions Granger cause technical innovation and FDI inflows. Air freight and insurance and financial services Granger cause FDI inflows and GHG emissions, respectively. The IRF and VDA estimates confirmed the viability of sustainable technological innovation and air freight pricing in GHG emissions' mitigation over the next 10 years. Thus, based on robust inferences, the following policy implications are proposed to support the post-Paris agreement (COP21) and the 2030 UN agenda on sustainable development:

i) Technological advancement in cleaner production, including upgrading renewable energy projects, electrified vehicles, and hybrid technology, are climate-resilient strategies which would be achieved through higher spending on $R \& D$ projects across countries.

ii) Air freight pricing would help improve air freight and logistics activities towards a more sustainable model, i.e., by shifting to renewable fuel-based activities, technology-improved logistics operations, and logistics environmental regulations. iii) Efficient air freight pricing would result in freight revenues available to support sustainable policy options, i.e., new emerging technological innovation-based markets and enhancing economic activities.

iv) Urgent need to improve insurance and financial activities to support logistics activities and climate-based financing by technological advancement and logistics pricing.

v) Urgent need for strict governmental environment-based reforms to limit polluting industries by advances in cleaner production, renewable energy sources, smart grid energy applications, electrified vehicles, and hybrid technologies. Massive environmental reforms are required across all countries to achieve sustainability.

These five important policy implications may set out environmental sustainability targets as suggested by the Paris Agreement (COP21) and 2030 United Nations sustainable development agenda through technology assisted growth, integrated climate-resilient projects, renewable energy reforms, energy and resource market financing and strict environmental regulatory mechanisms. Thus, it would help maintain the global temperature of less than $1.5^{\circ} \mathrm{C}$ through cooperation among the R\&D economies for globally shared prosperity.

\section{Acknowledgments}

Researchers Supporting Project number (RSP2022/87), King Saud University, Riyadh, Saudi Arabia.

\section{References}

Ahmed K, Ozturk I. 2018. What new technology means for the energy demand in China? A sustainable development perspective. Environmental Science and Pollution Research, 25: 29766-29771. https://doi.org/10.1007/ s11356-018-2957-3

Al Mamun M, Sohag K, Shahbaz M, Hammoudeh S. 2018. Financial markets, innovations and cleaner energy production in OECD countries. Energy Economics, 72: 236-254. https://doi.org/10.1016/j. eneco.2018.04.011

Aldakhil AM, Zaheer A, Younas S, Nassani AA, Abro MMQ, Zaman K. 2019. Efficiently managing green 
information and communication technologies, high-technology exports, and research and development expenditures: A case study. Journal of Cleaner Production, 240: 118164. https://doi.org/10.1016/j. jclepro.2019.118164

Atuonwu JC, Leadley C, Bosman A, Tassou SA, Lopez-Quiroga E, Fryer PJ. 2018. Comparative assessment of innovative and conventional food preservation technologies: Process energy performance and greenhouse gas emissions. Innovative food science \& emerging technologies, 50: 174-187. https://doi. org/10.1016/j.ifset.2018.09.008

Avetisyan M. 2018. Impacts of global carbon pricing on international trade, modal choice and emissions from international transport. Energy Economics, 76: 532548. https://doi.org/10.1016/j.eneco.2018.10.020

Batool R, Sharif A, Islam T, Zaman K, Shoukry AM, Sharkawy MA, Gani S, Aamir A, Hishan SS. 2019. Green is clean: the role of ICT in resource management. Environmental Science and Pollution Research, 26: 2534125358. https://doi.org/10.1007/s11356-019-05748-0

Bel G, Joseph S. 2018. Policy stringency under the European Union Emission trading system and its impact on technological change in the energy sector. Energy Policy, 117: 434-444. https://doi.org/10.1016/j.enpol.2018.03.041

Chen W, Lei Y. 2018. The impacts of renewable energy and technological innovation on environment-energy-growth nexus: New evidence from a panel quantile regression. Renewable Energy, 123: 1-14. https://doi. org/10.1016/j.renene.2018.02.026

CIGI 2017. Generating Growth from Innovation for the Low-carbon Economy: Exploring Safeguards in Finance and Regulation. Centre for International Governance Innovation (CIGI) Papers No.117, January 2017. Online available at: https://www.cigionline.org/ sites/default/files/documents/Paper\%20no.117_WEB. pdf (accessed 2019 September 14).

Dogan E, Ozturk I. 2017. The influence of renewable and non-renewable energy consumption and real income on $\mathrm{CO} 2$ emissions in the USA: evidence from structural break tests. Environmental Science and Pollution Research, 24: 10846-10854. https://doi.org/10.1007/ s11356-017-8786-y

Dumitrescu EI, Hurlin C. 2012. Testing for Granger non-causality in heterogeneous panels. Economic modelling, 29: 1450-1460. https://doi.org/10.1016/j. econmod.2012.02.014
Fernández-Fernández Y, Fernández-López M, Olmedillas-Blanco B. 2018. Innovation for sustainability: the impact of R\&D spending on CO2 emissions. Journal of cleaner production, 172: 3459-3467. https://doi. org/10.1016/j.jclepro.2017.11.001

Goetz AR, Alexander S. 2019. Urban Goods Movement and Local Climate Action Plans: Assessing Strategies to Reduce Greenhouse Gas Emissions from Urban Freight Transportation. Mineta Transportation Institute Publications. online available at: https://scholarworks.sjsu.edu/ mti_publications/262/ (accessed 2019 September 15).

Grubler A, Wilson C, Bento N, Boza-Kiss B, Krey V, Mc-Collum DL, Rao ND, Riahi K, Rogelj J, De Stercke S, Cullen J, Frank S, Fricko O, Guo F, Gidden M, Havlík P, Huppmann D, Kiesewetter G, Rafaj P, Schoepp W, Valin H. 2018. A low energy demand scenario for meeting the $1.5 \mathrm{C}$ target and sustainable development goals without negative emission technologies. Nature Energy, 3(6): 515-527. https://doi. org/10.1038/s41560-018-0172-6

Gupta M. 2016. Willingness to pay for carbon tax: A study of Indian road passenger transport. Transport Policy, 45: 46-54. https://doi.org/10.1016/j.tranpol.2015.09.001

Gupta M, Bandyopadhyay KR, Singh SK. 2019. Measuring effectiveness of carbon tax on Indian road passenger transport: A system dynamics approach. Energy Economics, 81: 341-354. https://doi.org/10.1016/j. eneco.2019.03.013

Hao H, Geng Y, Li W, Guo B. 2015. Energy consumption and GHG emissions from China's freight transport sector: scenarios through 2050. Energy Policy. 85: 94-101. https://doi.org/10.1016/j.enpol.2015.05.016

Hassan SA, Nosheen M, Rafaz N. 2019. Revealing the environmental pollution in nexus of aviation transportation in SAARC region. Environmental Science and Pollution Research, 26: 25092-25106. https://doi. org/10.1007/s11356-019-05648-3

Hishan SS, Khan A, Ahmad J, Hassan ZB, Zaman K, Qureshi MI. 2019. Access to clean technologies, energy, finance, and food: environmental sustainability agenda and its implications on Sub-Saharan African countries. Environmental Science and Pollution Research, 26: 16503-16518. https://doi.org/10.1007/ s11356-019-05056-7

Huang R, Riddle M, Graziano D, Warren J, Das S, Nimbalkar S, Cresko J, Masanet E. 2016. Energy and emissions saving potential of additive manufacturing: 
the case of lightweight aircraft components. Journal of Cleaner Production, 135: 1559-1570. https://doi. org/10.1016/j.jclepro.2015.04.109

IPCC 2018. Special Report: Global Warming of $1.5^{\circ} \mathrm{C}$. The Intergovernmental Panel on Climate Change, online available at: https://www.ipcc.ch/sr15/ (accessed 2019 September 14).

Jardón A, Kuik O, Tol RS. 2017. Economic growth and carbon dioxide emissions: An analysis of Latin America and the Caribbean. Atmósfera, 30(2): 87-100. https:// doi.org/10.20937/ATM.2017.30.02.02

Kato K, Galvao Jr, AF, Montes-Rojas GV. 2012. Asymptotics for panel quantile regression models with individual effects. Journal of Econometrics, 170: 76-91. https:// doi.org/10.1016/j.jeconom.2012.02.007

Khan MA, Ozturk I. 2020. Examining foreign direct investment and environmental pollution linkage in Asia. Environmental Science and Pollution Research, 27: 72447255. https://doi.org/10.1007/s11356-019-07387-x

Li M, Porter AL, Suominen A. 2018. Insights into relationships between disruptive technology/innovation and emerging technology: A bibliometric perspective. Technological Forecasting and Social Change, 129: 285-296. https://doi.org/10.1016/j.techfore.2017.09.032

Liu D, Guo X, Xiao B. 2019. What causes growth of global greenhouse gas emissions? Evidence from 40 countries. Science of The Total Environment, 661: 750766. https://doi.org/10.1016/j.scitotenv.2019.01.197

Long TB, Blok V, Coninx I. 2016. Barriers to the adoption and diffusion of technological innovations for climate-smart agriculture in Europe: evidence from the Netherlands, France, Switzerland and Italy. Journal of Cleaner Production, 112: 9-21. https://doi. org/10.1016/j.jclepro.2015.06.044

Lukkarinen J, Berg A, Salo M, Tainio P, Alhola K, Antikainen R. 2018. An intermediary approach to technological innovation systems (TIS) - The case of the cleantech sector in Finland. Environmental innovation and societal transitions, 26: 136-146. https:// doi.org/10.1016/j.eist.2017.04.003

Lybbert TJ, Sumner DA. 2012. Agricultural technologies for climate change in developing countries: Policy options for innovation and technology diffusion. Food Policy, 37: 114-123. https://doi.org/10.1016/j. foodpol.2011.11.001

Michaelowa A. 2015. Can insurance deal with negative effects arising from climate policy measures? In Climate Change and Insurance (pp. 80-90). Routledge.
Miyamoto M, Takeuchi K. 2019. Climate agreement and technology diffusion: Impact of the Kyoto Protocol on international patent applications for renewable energy technologies. Energy policy, 129: 1331-1338. https:// doi.org/10.1016/j.enpol.2019.02.053

Naz S, Sultan R, Zaman K, Aldakhil AM, Nassani AA, Abro MMQ. 2019. Moderating and mediating role of renewable energy consumption, FDI inflows, and economic growth on carbon dioxide emissions: evidence from robust least square estimator. Environmental Science and Pollution Research, 26: 2806-2819. https:// doi.org/10.1007/s11356-018-3837-6

Nerini F, Slob A, Engström RE, Trutnevyte E. 2019. A Research and Innovation Agenda for Zero-Emission European Cities. Sustainability, 11(6): 1692. https:// doi.org/10.3390/su11061692

Nikzad R, Sedigh G. 2017. Greenhouse gas emissions and green technologies in Canada. Environmental Development, 24: 99-108. https://doi.org/10.1016/j. envdev.2017.01.001

Nunes LJR, Godina R, Matias JCDO. 2019. Technological Innovation in Biomass Energy for the Sustainable Growth of Textile Industry. Sustainability, 11(2): 528. https://doi.org/10.3390/su11020528

Pizzol M. 2019. Deterministic and stochastic carbon footprint of intermodal ferry and truck freight transport across Scandinavian routes. Journal of Cleaner Production, 224: 626-636. https://doi.org/10.1016/j. jclepro.2019.03.270

Salahuddin M, Alam K, Ozturk I. 2016. The effects of Internet usage and economic growth on $\mathrm{CO} 2$ emissions in OECD countries: A panel investigation. Renewable and Sustainable Energy Reviews, 62: 1226-1235. https:// doi.org/10.1016/j.rser.2016.04.018

Santos G. 2017. Road fuel taxes in Europe: Do they internalize road transport externalities? Transport Policy, 53: 120-134. https://doi.org/10.1016/j.tranpol.2016.09.009

Sarkodie SA, Ozturk I. 2020. Investigating the environmental Kuznets curve hypothesis in Kenya: a multivariate analysis. Renewable and Sustainable Energy Reviews, 117: 109481. https://doi.org/10.1016/j. rser.2019.109481

Sarkodie SA, Strezov V. 2019. Effect of foreign direct investments, economic development and energy consumption on greenhouse gas emissions in developing countries. Science of the Total Environment, 646: 862871. https://doi.org/10.1016/j.scitotenv.2018.07.365 
Shahbaz M, Nasir MA, Roubaud D. 2018. Environmental degradation in France: the effects of FDI, financial development, and energy innovations. Energy Economics, 74: 843-857. https://doi.org/10.1016/j. eneco.2018.07.020

Sharif A, Raza SA, Ozturk I, Afshan S. 2019. The dynamic relationship of renewable and non-renewable energy consumption with carbon emission: a global study with the application of heterogeneous panel estimations. Renewable Energy, 133: 685-691. https://doi. org/10.1016/j.renene.2018.10.052

Shouket B, Zaman K, Nassani AA, Aldakhil AM, Abro MMQ. 2019. Management of green transportation: an evidence-based approach. Environmental Science and Pollution Research, 26: 12574-12589. https://doi. org/10.1007/s11356-019-04748-4

Shubbak MH. 2019. The technological system of production and innovation: The case of photovoltaic technology in China. Research Policy, 48(4): 993-1015. https:// doi.org/10.1016/j.respol.2018.10.003

Su HN, Moaniba IM. 2017. Does innovation respond to climate change? Empirical evidence from patents and greenhouse gas emissions. Technological Forecasting and Social Change, 122: 49-62. https://doi. org/10.1016/j.techfore.2017.04.017

UNFCCC 2017. Technological Innovation for the Paris Agreement: Implementing nationally determined contributions, national adaptation plans and mid-century strategies. The United Nations Framework Convention on Climate Change, Bonn, Germany. Online available at: https://unfccc.int/ttclear/misc_/StaticFiles/ gnwoerk_static/brief10/8c3ce94c20144fd5a8b0c06fefff6633/57440a5fa1244fd8b8cd13eb4413b4f6. pdf (accessed 2019 September 14).

Usman A, Ullah S, Ozturk I, Chishti MZ, Zafar SM. 2020. Analysis of asymmetries in the nexus among clean energy and environmental quality in Pakistan. Environmental Science and Pollution Research, 27: 2073620747. https://doi.org/10.1007/s11356-020-08372-5

Van Fan Y, Klemes JJ, Perry S, Lee CT. 2018. An Emissions Analysis for Environmentally Sustainable Freight Transportation Modes: Distance and Capacity. Chemical Engineering Transactions, 70: 505-510. https://doi. org/10.3303/CET1870085

Williams JH, DeBenedictis A, Ghanadan R, Mahone A, Moore J, Morrow III WR, Price S, Torn MS. 2012. The tech- nology path to deep greenhouse gas emissions cuts by 2050: the pivotal role of electricity.
Science, 335(6064): 53-59. https://doi.org/10.1126/ science. 1208365

World Bank 2019. World Development Indicator, World Bank, Washington DC.

Wu J, Ma Z, Liu Z, Lei CK. 2019. A contingent view of institutional environment, firm capability, and innovation performance of emerging multinational enterprises. Industrial Marketing Management, 82: 148-157. https:// doi.org/10.1016/j.indmarman.2019.01.018

Xue X, Zhang X, Wang L, Skitmore M, Wang Q. 2018. Analyzing collaborative relationships among industrialized construction technology innovation organizations: A combined SNA and SEM approach. Journal of Cleaner Production, 173: 265-277. https://doi. org/10.1016/j.jclepro.2017.01.009

Yalçınkaya Ö, Hüseyni İ, Çelik AK. 2017. The impact of total factor productivity on economic growth for developed and emerging countries: A second-generation panel data analysis. Margin: The Journal of Applied Economic Research, 11(4): 404-417. https:// doi.org/10.1177/0973801017722266

Yusuf M, Sabara Z, Wekke IS. 2019. Role of Innovation in Testing Environment Kuznets Curve: A Case of Indonesian Economy. International Journal of Energy Economics and Policy, 9(1): 276-281. https://doi. org/10.32479/ijeep.7230

Zahedi S, Batista-Foguet JM, van Wunnik L. 2019. Exploring the public's willingness to reduce air pollution and greenhouse gas emissions from private road transport in Catalonia. Science of the Total Environment, 646: 850-861. https://doi.org/10.1016/j. scitotenv.2018.07.361

Zhang N, Wang B, Chen Z. 2016. Carbon emissions reductions and technology gaps in the world's factory, 1990-2012. Energy Policy, 91: 28-37. https://doi. org/10.1016/j.enpol.2015.12.042

Zhang WF, Dou ZX, He P, Ju XT, Powlson D, Chadwick D, Norse D, Lu YL, Zhang Y, Wu L, Chen XP, Cassman KG, Zhang FS. 2013. New technologies reduce greenhouse gas emissions from nitrogenous fertilizer in China. Proceedings of the National Academy of Sciences, 110(21): 8375-8380. https://doi.org/10.1073/ pnas. 1210447110

Zhang Y, Na S, Niu J, Jiang B. 2018. The influencing factors, regional difference and temporal variation of industrial technology innovation: Evidence with the FOA-GRNN model. Sustainability, 10(1): 187. https:// doi.org/10.3390/su10010187 


\section{Supplementary Material}

Table SI. Principal Component Analysis (PCA) for Technology Innovation Index (TINDEX).

\begin{tabular}{|c|c|c|c|c|c|}
\hline \multicolumn{6}{|c|}{ Eigenvalues: $($ Sum $=4$, Average $=1)$} \\
\hline Number & Value & Difference & Proportion & $\begin{array}{c}\text { Cumulative } \\
\text { Value }\end{array}$ & $\begin{array}{l}\text { Cumulative } \\
\text { Proportion }\end{array}$ \\
\hline 1 & 1.619 & 0.244 & 0.404 & 1.619 & 0.404 \\
\hline 2 & 1.375 & 0.773 & 0.343 & 2.994 & 0.748 \\
\hline 3 & 0.601 & 0.198 & 0.150 & 3.5963 & 0.899 \\
\hline 4 & 0.403 & --- & 0.100 & 4 & 1 \\
\hline \multicolumn{6}{|c|}{ Eigenvectors (loadings): } \\
\hline Variable & PC 1 & PC 2 & PC 3 & PC 4 & \\
\hline TINOV_1 & 0.628 & -0.280 & 0.448 & -0.570 & \\
\hline TINOV_2 & 0.355 & 0.636 & 0.498 & 0.469 & \\
\hline TINOV_3 & 0.470 & -0.572 & -0.205 & 0.638 & \\
\hline TINOV_4 & 0.507 & 0.433 & -0.7122 & -0.215 & \\
\hline \multicolumn{6}{|c|}{ Ordinary correlations: } \\
\hline & TINOV1 & TINOV2 & TINOV3 & TINOV4 & \\
\hline TINOV_1 & 1 & & & & \\
\hline TINOV_2 & 0.141625 & 1 & & & \\
\hline TINOV_3 & 0.497567 & -0.171175 & 1 & & \\
\hline TINOV_4 & 0.205890 & 0.416831 & 0.078619 & 1 & \\
\hline
\end{tabular}


Table S2. Dumitrescu Hurlin Panel Causality Tests.

\begin{tabular}{|c|c|c|c|}
\hline Null Hypothesis: & W-Stat. & Zbar-Stat. & Prob. \\
\hline TINOVINDEX 少 GHG & 5.20111 & 7.06997 & 2.E-12 \\
\hline GHG & 3.67852 & 3.40158 & 0.0007 \\
\hline ATF t' GHG & 5.38831 & 7.52098 & 5.E-14 \\
\hline GHG " & 4.14349 & 4.52183 & 6.E-06 \\
\hline FPRICE 尘 GHG & 3.76676 & 3.61417 & 0.0003 \\
\hline GHG $\stackrel{\text { FPRICE }}{ }$ & 8.00943 & 13.8361 & 0.0000 \\
\hline FREV "步 GHG & 2.84295 & 1.38843 & 0.1650 \\
\hline GHG 此 FREV & 4.80693 & 6.12027 & 9.E-10 \\
\hline FDI $\stackrel{\mu}{t}$ GHG & 4.26128 & 4.80564 & 2.E-06 \\
\hline GHG"步FDI & 3.32739 & 2.55560 & 0.0106 \\
\hline IFS 㠩"GHG & 3.71429 & 3.48777 & 0.0005 \\
\hline $\mathrm{GHG}^{\prime \prime}$ IFS & 5.22585 & 7.12957 & 1.E-12 \\
\hline ATF ${ }^{\text {t" TINOVINDEX }}$ & 3.12196 & 2.06066 & 0.0393 \\
\hline TINOVINDEX 贯 ATF & 3.09398 & 1.99325 & 0.0462 \\
\hline FPRICE $\stackrel{t}{7}$ TINÖVINDEX & 3.44860 & 2.84764 & 0.0044 \\
\hline TINOVINDEX & 3.71544 & 3.49055 & 0.0005 \\
\hline FREV 步 TINOVINDEX & 3.06784 & 1.93028 & 0.0536 \\
\hline 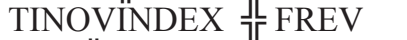 & 3.55222 & 3.09728 & 0.0020 \\
\hline FDI 步TINOVINDEX & 3.29888 & 2.48693 & 0.0129 \\
\hline TINOVINDEX 步FDI & 3.03813 & 1.85868 & 0.0631 \\
\hline IFS 点e TINOVINDEX & 4.75054 & 5.98441 & 2.E-09 \\
\hline TINOVINDEX 卢 IFS & 4.94154 & 6.44459 & 1.E-10 \\
\hline FPRICE 步ATF & 4.85606 & 6.23864 & 4.E-10 \\
\hline ATF $\stackrel{\text { HPRICE }}{7 \text { FPR }}$ & 4.90792 & 6.36359 & 2.E-10 \\
\hline FREV 常 ATF & 6.24772 & 9.59156 & 0.0000 \\
\hline ATF $\underset{\text { H }}{\mathrm{F} R E V}$ & 7.23952 & 11.9811 & 0.0000 \\
\hline FDI 岇ATF & 4.02515 & 4.23671 & 2.E-05 \\
\hline ATF $\underset{\pi}{\pi}$ FDI & 3.09510 & 1.99594 & 0.0459 \\
\hline IFS 第ATF & 4.74880 & 5.98021 & 2.E-09 \\
\hline ATF $\stackrel{L}{7}$ IFS & 4.89463 & 6.33156 & 2.E-10 \\
\hline FREV & 4.84142 & 6.20337 & 6.E-10 \\
\hline FPRICE 云 FREV & 4.40877 & 5.16098 & 2.E-07 \\
\hline FDI 步 FPRICE & 2.68430 & 1.00620 & 0.3143 \\
\hline FPRICE 肾 FDI & 2.94947 & 1.64507 & 0.1000 \\
\hline IFS ז FPRICE & 4.17232 & 4.59130 & 4.E-06 \\
\hline FPRICE 步 IFS & 3.19262 & 2.23090 & 0.0257 \\
\hline FDI & 3.46386 & 2.88441 & 0.0039 \\
\hline FREV 止 FDI & 3.44165 & 2.83088 & 0.0046 \\
\hline IFS ז FREV & 4.93863 & 6.43757 & 1.E-10 \\
\hline FREV 步 IFS & 4.39860 & 5.13648 & 3.E-07 \\
\hline IFS 紧FDI & 2.45126 & 0.44473 & 0.6565 \\
\hline FDI 步 IFS & 3.84106 & 3.79321 & 0.0001 \\
\hline
\end{tabular}

Note: 步 shows 'does not Granger cause'. 
Table S3. Other IRF Estimates.

\begin{tabular}{cccccccc}
\hline \multicolumn{7}{c}{ Response of TINOVINDEX: } \\
\hline Period & GHG & TINOVINDEX & ATF & FPRICE & FREV & FDI & IFS \\
\hline 1 & 0.006996 & 0.143862 & 0 & 0 & 0 & 0 & 0 \\
2 & 0.007779 & 0.154365 & $1.44 \mathrm{E}-05$ & 0.001921 & -0.006198 & -0.008429 & -0.003595 \\
3 & 0.006053 & 0.154358 & -0.002255 & 0.002796 & -0.008228 & -0.008032 & -0.004784 \\
4 & 0.005108 & 0.153868 & -0.003335 & 0.003328 & -0.009922 & -0.007133 & -0.005408 \\
5 & 0.003867 & 0.153326 & -0.003981 & 0.003661 & -0.010710 & -0.006635 & -0.005961 \\
6 & 0.002743 & 0.152780 & -0.004185 & 0.003898 & -0.011011 & -0.006324 & -0.006468 \\
7 & 0.001578 & 0.152223 & -0.004155 & 0.004080 & -0.011113 & -0.006146 & -0.006945 \\
8 & 0.000414 & 0.151661 & -0.004021 & 0.004237 & -0.011112 & -0.006066 & -0.007405 \\
9 & -0.000765 & 0.151100 & -0.003827 & 0.004379 & -0.011060 & -0.006044 & -0.007852 \\
10 & -0.001957 & 0.150541 & -0.003599 & 0.004516 & -0.010987 & -0.006059 & -0.008288 \\
\hline
\end{tabular}

Response of ATF:

\begin{tabular}{cccccccc}
\hline Period & GHG & TINOVINDEX & ATF & FPRICE & FREV & FDI & IFS \\
\hline 1 & 22.53127 & 28.02587 & 474.0766 & 0 & 0 & 0 & 0 \\
2 & 42.69527 & 10.94580 & 406.5271 & 0.478103 & -153.9177 & -51.09418 & -5.203977 \\
3 & 56.95983 & 15.98292 & 350.9324 & -2.599750 & -174.8257 & -79.75076 & -13.46052 \\
4 & 81.26306 & 22.93814 & 338.5393 & -6.353762 & -192.9530 & -85.60743 & -17.94478 \\
5 & 102.9077 & 28.19438 & 327.2605 & -10.15455 & -206.4116 & -89.74252 & -21.69883 \\
6 & 126.3216 & 33.34876 & 318.9573 & -13.77222 & -213.6043 & -91.87496 & -25.06563 \\
7 & 150.1104 & 38.34796 & 313.1534 & -17.21821 & -218.4319 & -92.74849 & -28.07165 \\
8 & 174.5420 & 43.18261 & 308.1302 & -20.47783 & -221.9690 & -93.25879 & -30.86308 \\
9 & 199.4598 & 47.90528 & 303.4603 & -23.59954 & -224.6929 & -93.58605 & -33.50653 \\
10 & 224.8829 & 52.52854 & 298.8684 & -26.62347 & -226.9593 & -93.82003 & -36.03283 \\
\hline
\end{tabular}

Response of FPRICE:

\begin{tabular}{cccccccc}
\hline Period & GHG & TINOVINDEX & ATF & FPRICE & FREV & FDI & IFS \\
\hline 1 & -0.583654 & 0.001513 & 0.079817 & 11.03347 & 0 & 0 & 0 \\
2 & 1.217401 & -0.360767 & 0.159501 & 7.337689 & 0.048301 & -0.011956 & 0.473231 \\
3 & 0.213671 & -0.333651 & 0.249345 & 4.931379 & 0.120002 & 0.040648 & 0.251233 \\
4 & 0.324511 & -0.303051 & 0.153418 & 3.343073 & 0.129077 & -0.005239 & 0.116981 \\
5 & 0.126807 & -0.281641 & 0.138641 & 2.257896 & 0.128704 & -0.005285 & 0.023147 \\
6 & 0.085880 & -0.267112 & 0.096954 & 1.530020 & 0.108262 & -0.014243 & -0.038875 \\
7 & 0.025117 & -0.256839 & 0.069565 & 1.036608 & 0.093033 & -0.015922 & -0.080494 \\
8 & -0.005094 & -0.249611 & 0.046538 & 0.703638 & 0.078996 & -0.016579 & -0.107446 \\
9 & -0.029856 & -0.244589 & 0.030164 & 0.478276 & 0.068507 & -0.015714 & -0.124585 \\
10 & -0.045624 & -0.241075 & 0.018033 & 0.325901 & 0.060722 & -0.014496 & -0.134975 \\
\hline
\end{tabular}

Response of FREV:

\begin{tabular}{cccccccc}
\hline Period & GHG & TINOVINDEX & ATF & FPRICE & FREV & FDI & IFS \\
\hline 1 & -43750.29 & 8254.447 & 1152528. & 61020.13 & 2306578. & 0 & 0 \\
2 & 108917.5 & -46661.81 & 1322306. & 85724.65 & 682997.2 & 140990.1 & 29035.25 \\
3 & -8148.433 & -68364.28 & 642311.3 & 82764.53 & 235642.9 & -98752.50 & -25948.70 \\
4 & 28956.17 & -40777.13 & 459792.6 & 67753.64 & 86959.10 & -115140.8 & -52998.51 \\
5 & 29818.73 & -29850.49 & 375391.0 & 49918.80 & -38797.91 & -108548.4 & -65171.70 \\
6 & 44669.53 & -22961.48 & 313181.1 & 34570.53 & -100600.1 & -105436.4 & -73564.14 \\
7 & 58886.98 & -16807.72 & 282549.3 & 21517.11 & -131305.3 & -98240.08 & -78708.90 \\
8 & 75799.72 & -11796.70 & 265254.2 & 11121.96 & -148824.5 & -92358.72 & -81930.90 \\
9 & 93263.65 & -7379.804 & 254534.3 & 2898.216 & -158461.6 & -88225.32 & -84155.74 \\
10 & 111668.2 & -3286.634 & 247410.4 & -3608.250 & -164053.3 & -85415.35 & -85769.03 \\
\hline
\end{tabular}


Table S3. Other IRF Estimates.

\begin{tabular}{cccccccc}
\hline \multicolumn{7}{c}{ Response of FDI: } \\
\hline Period & GHG & TINOVINDEX & ATF & FPRICE & FREV & FDI & IFS \\
\hline 1 & $1.66 \mathrm{E}+09$ & $4.19 \mathrm{E}+08$ & $2.20 \mathrm{E}+09$ & $1.56 \mathrm{E}+08$ & $1.58 \mathrm{E}+09$ & $2.60 \mathrm{E}+10$ & 0 \\
2 & $2.06 \mathrm{E}+09$ & $4.64 \mathrm{E}+08$ & $1.29 \mathrm{E}+09$ & $-2.89 \mathrm{E}+08$ & $-3.37 \mathrm{E}+09$ & $1.40 \mathrm{E}+10$ & $1.39 \mathrm{E}+09$ \\
3 & $1.91 \mathrm{E}+09$ & $5.53 \mathrm{E}+08$ & $6.87 \mathrm{E}+08$ & $-4.37 \mathrm{E}+08$ & $-1.14 \mathrm{E}+09$ & $7.16 \mathrm{E}+09$ & $1.24 \mathrm{E}+09$ \\
4 & $2.31 \mathrm{E}+09$ & $6.00 \mathrm{E}+08$ & $1.63 \mathrm{E}+09$ & $-4.72 \mathrm{E}+08$ & $-9.08 \mathrm{E}+08$ & $4.01 \mathrm{E}+09$ & $1.27 \mathrm{E}+09$ \\
5 & $2.42 \mathrm{E}+09$ & $5.72 \mathrm{E}+08$ & $1.69 \mathrm{E}+09$ & $-4.62 \mathrm{E}+08$ & $-1.09 \mathrm{E}+09$ & $2.07 \mathrm{E}+09$ & $1.25 \mathrm{E}+09$ \\
6 & $2.60 \mathrm{E}+09$ & $5.82 \mathrm{E}+08$ & $1.62 \mathrm{E}+09$ & $-4.42 \mathrm{E}+08$ & $-1.16 \mathrm{E}+09$ & $9.82 \mathrm{E}+08$ & $1.22 \mathrm{E}+09$ \\
7 & $2.77 \mathrm{E}+09$ & $6.02 \mathrm{E}+08$ & $1.57 \mathrm{E}+09$ & $-4.28 \mathrm{E}+08$ & $-1.25 \mathrm{E}+09$ & $3.90 \mathrm{E}+08$ & $1.18 \mathrm{E}+09$ \\
8 & $2.94 \mathrm{E}+09$ & $6.23 \mathrm{E}+08$ & $1.50 \mathrm{E}+09$ & $-4.20 \mathrm{E}+08$ & $-1.32 \mathrm{E}+09$ & 58837400 & $1.14 \mathrm{E}+09$ \\
9 & $3.11 \mathrm{E}+09$ & $6.46 \mathrm{E}+08$ & $1.44 \mathrm{E}+09$ & $-4.20 \mathrm{E}+08$ & $-1.38 \mathrm{E}+09$ & $-1.24 \mathrm{E}+08$ & $1.10 \mathrm{E}+09$ \\
10 & $3.29 \mathrm{E}+09$ & $6.69 \mathrm{E}+08$ & $1.39 \mathrm{E}+09$ & $-4.25 \mathrm{E}+08$ & $-1.41 \mathrm{E}+09$ & $-2.24 \mathrm{E}+08$ & $1.07 \mathrm{E}+09$ \\
\hline & & & & & & \\
\hline Period & GHG & TINOVINDEX & ATF & FPRICE & FREV & FDI & IFS \\
\hline 1 & -0.013793 & 0.033542 & 0.066385 & -0.022186 & -0.059138 & 0.051513 & 1.182659 \\
2 & 0.000789 & 0.088794 & 0.032260 & -0.015979 & -0.059183 & 0.081600 & 1.135451 \\
3 & -0.003939 & 0.096597 & 0.044148 & -0.018128 & -0.057201 & 0.109064 & 1.113183 \\
4 & -0.003405 & 0.100000 & 0.050723 & -0.019351 & -0.061962 & 0.122594 & 1.092128 \\
5 & -0.004393 & 0.103254 & 0.056456 & -0.020271 & -0.064711 & 0.127765 & 1.071426 \\
6 & -0.004101 & 0.106556 & 0.062746 & -0.020825 & -0.067534 & 0.128703 & 1.051132 \\
7 & -0.003618 & 0.109832 & 0.068904 & -0.021137 & -0.070658 & 0.127176 & 1.031167 \\
8 & -0.002599 & 0.113121 & 0.074794 & -0.021272 & -0.073942 & 0.124292 & 1.011506 \\
9 & -0.001164 & 0.116435 & 0.080475 & -0.021303 & -0.077348 & 0.120710 & 0.992137 \\
10 & 0.000723 & 0.119773 & 0.085942 & -0.021275 & -0.080839 & 0.116772 & 0.973056 \\
\hline
\end{tabular}


Table S4. Other VDA Estimates.

\begin{tabular}{ccccccccc}
\hline \multicolumn{7}{c}{ Variance Decomposition of TINOVINDEX: } \\
\hline Period & S.E. & GHG & TINOVINDEX & ATF & FPRICE & FREV & FDI & IFS \\
\hline 1 & 0.144032 & 0.235898 & 99.76410 & 0.000000 & 0.000000 & 0.000000 & 0.000000 & 0.000000 \\
2 & 0.211566 & 0.244513 & 99.47380 & $4.66 E-07$ & 0.008246 & 0.085837 & 0.158729 & 0.028874 \\
3 & 0.262281 & 0.212352 & 99.36014 & 0.007392 & 0.016728 & 0.154265 & 0.197069 & 0.052052 \\
4 & 0.304456 & 0.185740 & 99.28039 & 0.017483 & 0.024365 & 0.220697 & 0.201146 & 0.070179 \\
5 & 0.341234 & 0.160703 & 99.22235 & 0.027525 & 0.030908 & 0.274199 & 0.197931 & 0.086380 \\
6 & 0.374200 & 0.139007 & 99.17958 & 0.035400 & 0.036552 & 0.314598 & 0.193156 & 0.101703 \\
7 & 0.404281 & 0.120613 & 99.14667 & 0.040890 & 0.041501 & 0.345083 & 0.188596 & 0.116642 \\
8 & 0.432081 & 0.105684 & 99.11936 & 0.044460 & 0.045947 & 0.368243 & 0.184818 & 0.131485 \\
9 & 0.458017 & 0.094333 & 99.09476 & 0.046548 & 0.050034 & 0.386027 & 0.181894 & 0.146402 \\
10 & 0.482396 & 0.086685 & 99.07080 & 0.047528 & 0.053867 & 0.399866 & 0.179752 & 0.161499 \\
\hline
\end{tabular}

Variance Decomposition of ATF:

\begin{tabular}{ccccccccc}
\hline Period & S.E. & GHG & TINOVINDEX & ATF & FPRICE & FREV & FDI & IFS \\
\hline 1 & 475.4384 & 0.224586 & 0.347480 & 99.42793 & 0.000000 & 0.000000 & 0.000000 & 0.000000 \\
2 & 647.7478 & 0.555450 & 0.215755 & 92.95377 & $5.45 \mathrm{E}-05$ & 5.646316 & 0.622201 & 0.006454 \\
3 & 763.7689 & 0.955693 & 0.198976 & 87.96995 & 0.001198 & 9.300653 & 1.537826 & 0.035702 \\
4 & 866.0274 & 1.623813 & 0.224915 & 83.70299 & 0.006314 & 12.19802 & 2.173247 & 0.070704 \\
5 & 959.0210 & 2.475602 & 0.269842 & 79.90190 & 0.016361 & 14.57956 & 2.647884 & 0.108850 \\
6 & 1045.662 & 3.541744 & 0.328690 & 76.51370 & 0.031109 & 16.43648 & 2.999255 & 0.149021 \\
7 & 1128.219 & 4.812631 & 0.397878 & 73.42994 & 0.050014 & 17.86743 & 3.252192 & 0.189918 \\
8 & 1208.094 & 6.284645 & 0.474771 & 70.54635 & 0.072351 & 18.95872 & 3.432267 & 0.230899 \\
9 & 1286.306 & 7.948107 & 0.557491 & 67.79386 & 0.097480 & 19.77463 & 3.556907 & 0.271527 \\
10 & 1363.656 & 9.791598 & 0.644422 & 65.12455 & 0.124852 & 20.36497 & 3.638188 & 0.311419 \\
\hline
\end{tabular}

Variance Decomposition of FPRICE:

\begin{tabular}{ccccccccc}
\hline Period & S.E. & GHG & TINOVINDEX & ATF & FPRICE & FREV & FDI & IFS \\
\hline 1 & 11.04919 & 0.279029 & $1.87 \mathrm{E}-06$ & 0.005218 & 99.71575 & 0.000000 & 0.000000 & 0.000000 \\
2 & 13.33380 & 1.025207 & 0.073207 & 0.017893 & 98.75634 & 0.001312 & $8.04 \mathrm{E}-05$ & 0.125961 \\
3 & 14.22699 & 0.923077 & 0.119303 & 0.046433 & 98.76021 & 0.008267 & 0.000887 & 0.141826 \\
4 & 14.62308 & 0.922995 & 0.155877 & 0.054959 & 98.70905 & 0.015617 & 0.000852 & 0.140646 \\
5 & 14.80082 & 0.908300 & 0.188365 & 0.062421 & 98.67973 & 0.022806 & 0.000845 & 0.137533 \\
6 & 14.88310 & 0.901614 & 0.218498 & 0.065977 & 98.64844 & 0.027846 & 0.000927 & 0.136699 \\
7 & 14.92207 & 0.897195 & 0.246984 & 0.067806 & 98.61650 & 0.031587 & 0.001036 & 0.138896 \\
8 & 14.94141 & 0.894885 & 0.274254 & 0.068601 & 98.58310 & 0.034301 & 0.001156 & 0.143707 \\
9 & 14.95181 & 0.894040 & 0.300632 & 0.068912 & 98.54835 & 0.036353 & 0.001265 & 0.150451 \\
10 & 14.95812 & 0.894215 & 0.326353 & 0.068999 & 98.51264 & 0.037970 & 0.001358 & 0.158466
\end{tabular}

VarianceDecompositionofFREV:

\begin{tabular}{ccccccccc}
\hline Period & S.E. & GHG & TINOVINDEX & ATF & FPRICE & FREV & FDI & IFS \\
\hline 1 & 2579598. & 0.028765 & 0.001024 & 19.96176 & 0.055955 & 79.95250 & 0.000000 & 0.000000 \\
2 & 2985199. & 0.154601 & 0.025198 & 34.52665 & 0.124247 & 64.93678 & 0.223065 & 0.009460 \\
3 & 3066190. & 0.147248 & 0.073596 & 37.11502 & 0.190630 & 62.14221 & 0.315165 & 0.016129 \\
4 & 3105423. & 0.152245 & 0.088990 & 38.37537 & 0.233446 & 60.66038 & 0.444724 & 0.044850 \\
5 & 3131514. & 0.158786 & 0.096600 & 39.17558 & 0.254983 & 59.66914 & 0.557499 & 0.087418 \\
6 & 3151956. & 0.176817 & 0.100658 & 39.65633 & 0.263716 & 58.99953 & 0.662188 & 0.140760 \\
7 & 3170483. & 0.209254 & 0.102295 & 39.98843 & 0.265249 & 58.48354 & 0.750484 & 0.200750 \\
8 & 3188373. & 0.263432 & 0.102520 & 40.23307 & 0.263497 & 58.04695 & 0.825997 & 0.264536 \\
9 & 3206126. & 0.345141 & 0.101917 & 40.41901 & 0.260669 & 57.65016 & 0.892597 & 0.330513 \\
10 & 3224053. & 0.461278 & 0.100891 & 40.55966 & 0.257903 & 57.26976 & 0.952887 & 0.397619 \\
\hline
\end{tabular}


Table S4. Other VDA Estimates.

\begin{tabular}{ccccccccc}
\hline \multicolumn{7}{c}{} & \multicolumn{7}{c}{ Variance Decomposition of FDI: } \\
Period & S.E. & GHG & TINOVINDEX & ATF & FPRICE & FREV & FDI & IFS \\
\hline 1 & $2.62 \mathrm{E}+10$ & 0.402257 & 0.025522 & 0.705152 & 0.003517 & 0.363134 & 98.50042 & 0.000000 \\
2 & $3.00 \mathrm{E}+10$ & 0.776554 & 0.043338 & 0.720409 & 0.011936 & 1.531888 & 96.70186 & 0.214011 \\
3 & $3.10 \mathrm{E}+10$ & 1.109328 & 0.072444 & 0.725464 & 0.031045 & 1.572676 & 96.12904 & 0.360006 \\
4 & $3.14 \mathrm{E}+10$ & 1.618996 & 0.106813 & 0.972909 & 0.052747 & 1.612842 & 95.12278 & 0.512913 \\
5 & $3.17 \mathrm{E}+10$ & 2.173851 & 0.137600 & 1.239666 & 0.073173 & 1.704131 & 94.01064 & 0.660940 \\
6 & $3.19 \mathrm{E}+10$ & 2.808616 & 0.168952 & 1.479595 & 0.091383 & 1.813913 & 92.84014 & 0.797407 \\
7 & $3.21 \mathrm{E}+10$ & 3.511767 & 0.201760 & 1.697595 & 0.107895 & 1.941293 & 91.61810 & 0.921590 \\
8 & $3.24 \mathrm{E}+10$ & 4.287142 & 0.236053 & 1.889333 & 0.123269 & 2.082034 & 90.34880 & 1.033368 \\
9 & $3.26 \mathrm{E}+10$ & 5.134798 & 0.271903 & 2.057103 & 0.138070 & 2.229950 & 89.03502 & 1.133156 \\
10 & $3.28 \mathrm{E}+10$ & 6.056529 & 0.309231 & 2.203576 & 0.152713 & 2.380553 & 87.67582 & 1.221574 \\
\hline & & & & & & & & \\
\hline Period & S.E. & GHG & TINOVINDEX & ATF & FPRICE & FREV & FDI & IFS \\
\hline 1 & 1.187876 & 0.013483 & 0.079734 & 0.312321 & 0.034883 & 0.247851 & 0.188061 & 99.12367 \\
2 & 1.649133 & 0.007018 & 0.331274 & 0.200311 & 0.027487 & 0.257386 & 0.342405 & 98.83412 \\
3 & 1.996398 & 0.005178 & 0.460167 & 0.185588 & 0.027001 & 0.257726 & 0.532094 & 98.53225 \\
4 & 2.282581 & 0.004184 & 0.543944 & 0.191349 & 0.027842 & 0.270840 & 0.695495 & 98.26635 \\
5 & 2.528422 & 0.003711 & 0.610079 & 0.205804 & 0.029119 & 0.286235 & 0.822167 & 98.04289 \\
6 & 2.744934 & 0.003372 & 0.668324 & 0.226870 & 0.030462 & 0.303392 & 0.917424 & 97.85015 \\
7 & 2.938777 & 0.003094 & 0.722742 & 0.252903 & 0.031750 & 0.322497 & 0.987661 & 97.67935 \\
8 & 3.114373 & 0.002824 & 0.775471 & 0.282864 & 0.032936 & 0.343525 & 1.038701 & 97.52368 \\
9 & 3.274858 & 0.002567 & 0.827738 & 0.316206 & 0.034018 & 0.366465 & 1.075255 & 97.37775 \\
10 & 3.422556 & 0.002355 & 0.880305 & 0.352557 & 0.035009 & 0.391307 & 1.100860 & 97.23761 \\
\hline
\end{tabular}

